\title{
Oregano Oil, Epsilon-Polylysine and Citric Acid Assisted Inactivation of Salmonella in Two Kinds of Tahini during Thermal Treatment and Storage
}

\author{
Yuanmei Xu ${ }^{1}$, Xiangyu Guan ${ }^{1}$, Biying Lin ${ }^{1}$, Rui Li ${ }^{1}$ and Shaojin Wang ${ }^{1,2, *}$ \\ 1 College of Mechanical and Electronic Engineering, Northwest A\&F University, Yangling 712100, China; \\ yuanmeixu@nwafu.edu.cn (Y.X.); xiangyuguan@nwafu.edu.cn (X.G.); linbiying@nwafu.edu.cn (B.L.); \\ ruili1216@nwafu.edu.cn (R.L.) \\ 2 Department of Biological Systems Engineering, Washington State University, Pullman, WA 99164-6120, USA \\ * Correspondence: shaojinwang@nwsuaf.edu.cn; Tel.: +86-29-87092391; Fax: +86-29-87091737
}

Citation: Xu, Y.; Guan, X.; Lin, B.; Li, R.; Wang, S. Oregano Oil, Epsilon-Polylysine and Citric Acid Assisted Inactivation of Salmonella in Two Kinds of Tahini during Thermal Treatment and Storage. Foods 2021, 10 1272. https://doi.org/10.3390/ foods10061272

Received: 17 March 2021

Accepted: 29 May 2021

Published: 3 June 2021

Publisher's Note: MDPI stays neutra with regard to jurisdictional claims in published maps and institutional affiliations.

Copyright: (c) 2021 by the authors. Licensee MDPI, Basel, Switzerland. This article is an open access article distributed under the terms and conditions of the Creative Commons Attribution (CC BY) license (https:// creativecommons.org/licenses/by/ $4.0 /)$.

\begin{abstract}
Tahini and tahini-based products are popular with consumers due to their special flavor and high nutritional values, but often have been linked to Salmonella outbreaks. The objective of this study was to compare effects of different kinds of natural antimicrobials on Salmonella inactivation in undiluted and diluted tahini during thermal treatment and storage. Results showed that the Weibull model was more suitable to describe the thermal inactivation behavior of S. montevideo CICC21588 in two kinds of tahini than the first-order model. Inactivation curves were concave-upward in undiluted tahini but concave-downward in diluted tahini. During storage of undiluted tahini, 3\% oregano oil caused extra 1.44 or $0.80 \log \mathrm{CFU} / \mathrm{g}$ reductions after 7 days at $25^{\circ} \mathrm{C}$ or $4{ }^{\circ} \mathrm{C}$ compared to the control and $0.5 \%$ citric acid caused an extra reduction of $0.75 \log \mathrm{CFU} / \mathrm{g}$ after $7 \mathrm{~d}$ at $4{ }^{\circ} \mathrm{C}$. For diluted tahini, $2-3 \%$ oregano oil and $0.4-0.5 \%$-polylysine reduced more populations compared to undiluted tahini. These antimicrobials all inhibited the growth of $S$. montevideo during $24 \mathrm{~h}$ at $25^{\circ} \mathrm{C}$ and $\varepsilon$-polylysine had the best effect. Furthermore, these antimicrobials enhanced the Salmonella inactivation in diluted tahini during thermal treatment, and there was less of a synergistic effect of thermal and antimicrobials in undiluted tahini due to less sublethal injured cells caused by heat. This study may provide useful information for Salmonella inactivation in tahini.
\end{abstract}

Keywords: Salmonella montevideo CICC21588; tahini; natural antimicrobials; thermal inactivation; antimicrobial effects

\section{Introduction}

Tahini (sesame seeds paste) is a well-known ready-to-eat product in Middle Eastern and Eastern Mediterranean countries due to its special flavor and high nutritional value [1]. It has 57-65\% fat, $6.4-9.0 \%$ carbohydrate, $23-27 \%$ protein and low water content $(<1 \%)$ [2]. Tahini not only can be consumed directly, but also mixed with other ingredients to make tahini-based products, such as hummus, halva, baba ghanoush and various salad dressings [3-5]. In Chinese diet, tahini has been usually diluted with 1-3 times water or adding other components according to personal tastes to make noodle dip or hot pot dip [6].

However, a number of Salmonella illness outbreaks and recalls related to the tahini and tahini-based products consumption happened at 2001 [7], 2002-2003 [8], 2011 [9], 2012 [10], 2013 [11], 2016-2017 [12], and 2018-2019 [13,14], resulting in a serious economic loss and posing a big threat to people's lives. Figure 1 shows the Salmonella illness outbreaks happened at 2001-2019, including Salmonella serotypes, outbreak locations, associated products, and product sources.

Generally, the production of tahini involves soaking, dehulling, roasting, and milling of sesame seeds [15] and the roasting treatment $\left(110 \sim 150{ }^{\circ} \mathrm{C}\right.$ for $\left.30-60 \mathrm{~min}\right)$ is sufficient to inactivate most food pathogens [16]. However, some bacteria might survive at the roasting 
process due to the insufficient heating and the increase of thermal resistance of bacteria on sesame seeds with low water activity $\left(\mathrm{a}_{\mathrm{w}}\right)[16,17]$. In addition, contamination might occur during the milling or packaging process after thermal treatment. Although Salmonella cannot grow in tahini due to its low $\mathrm{a}_{\mathrm{w}}(0.16-0.25)$, the high fat content may help them persist for a long period in low $\mathrm{a}_{\mathrm{w}}$ environment $[15,17]$ and also improve their survival rate in gastrointestinal environment, resulting in a reduction of the dose-response curve [18]. Furthermore, tahini is used commercially as a common ingredient to prepare ready-to-eat tahini-based products or at home or restaurant to prepare diluted tahini by adding different proportions of water as needed. These products are not consistently refrigerated and may be held at room temperature for several hours. High water content and nutrition in these tahini-based products provide a suitable environment for pathogens to grow, posing a threat to consumer health. Therefore, it is necessary to explore effective methods to control Salmonella contamination in tahini or tahini-based products.

\begin{tabular}{|c|c|c|c|c|c|c|}
\hline \multicolumn{7}{|c|}{ Outbreak-associated S. enterica serovars } \\
\hline$S$. Typhimurium DT 104 & S. Montevideo & $\begin{array}{l}S \text {. Bovismorbificans } \\
S . \text { Cubana }\end{array}$ & $\begin{array}{l}\text { S. Montevideo } \\
\text { S. Mbandaka } \\
\text { S. Maastricht }\end{array}$ & $\begin{array}{l}S . \text { Montevideo } \\
S \text {. Mbandaka }\end{array}$ & $\begin{array}{l}\text { Salmonella enterica } \\
11: z 41: e, n, z 15 \\
\text { (new serotype) }\end{array}$ & S. Concord \\
\hline $\begin{array}{l}\text { Outbreak-associated } \\
\text { Halva }\end{array}$ & $\begin{array}{l}\text { products } \\
\text { Halva }\end{array}$ & Hummus & Hummus & Tahini & Tahini & Tahini \\
\hline 2001 & 2002-2003 & 2011 & 2012 & 2013 & 2016-2017 & 2018-2019 \\
\hline $\begin{array}{l}\text { Outbreak location(s) } \\
\text { Australia, Sweden, } \\
\text { Norway, and Germany }\end{array}$ & $\begin{array}{l}\text { New Zealand and } \\
\text { Australia }\end{array}$ & Canada and USA & New Zealand & USA & $\begin{array}{l}\text { Greece, Germany, } \\
\text { Czech Republic, } \\
\text { Luxembourg }\end{array}$ & USA \\
\hline $\begin{array}{c}\text { Product source } \\
\text { Turkey }\end{array}$ & Egypt and Lebanor & Lebanon & Turkey & Turkey & & Israel \\
\hline
\end{tabular}

Figure 1. Salmonella outbreaks associated with the tahini or tahini-based products.

In recent years, the interest in using natural antimicrobials to control pathogens in the food industry has increased due to their safety. Essential oils (EOs), $\varepsilon$-polylysine ( $\varepsilon$-PL) and organic acid, have been widely studied in many food products to control the growth of pathogens, such as fresh lettuce [19], beef [20], milk [21], almond and pine nut kernels [22]. Currently, the most undiluted tahini currently in the market contains no antimicrobials, but tahini-based products often contain artificial preservatives. Therefore, it is necessary to investigate the potential applications of natural antimicrobials to control pathogens in tahini or tahini-based products during storage. Furthermore, natural antimicrobials have been widely applied to assist microbial inactivation during thermal processing of various products to save heating time or guarantee food quality [23]. However, limited information is available on the pathogen inactivation of natural antimicrobials during thermal treatments of tahini and tahini-based products.

The objectives of this study were (1) to determine thermal inactivation kinetics of Salmonella in undiluted or diluted tahini, (2) to evaluate the sublethal injured cells by thermal treatments in undiluted or diluted tahini, (3) to evaluate the inhibitory effects of oregano oil, $\varepsilon$-PL and citric acid in undiluted or diluted tahini during storage and (4) to evaluate the synergistic effects of heating and antimicrobials in undiluted or diluted tahini.

\section{Materials and Methods}

\subsection{Salmonella Strains and Culture Preparation}

Four Salmonella enterica serotypes were used in this study. Salmonella montevideo CICC21588 was obtained from the China Center of Industrial Culture Collection. Salmonella typhimurium CMCC50115 was obtained from National Center for Medical Culture Collections. Salmonella mbandaka NYS5-8 and Salmonella enteritidi R8-1-1 were provided by the College of Food Science and Engineering, Northwest A \& F University, Yangling, China. All strains were stored at $-20{ }^{\circ} \mathrm{C}$ with $20 \%$ glycerol. Prior to the experiment, one loopful of frozen culture was streaked onto tryptic soy agar (TSA; Beijing Land Bridge, Beijing, China) plates and incubated at $37^{\circ} \mathrm{C}$ for $24 \mathrm{~h}$. A single colony was transferred to $30 \mathrm{~mL}$ of tryptic soy broth (TSB; Beijing Land Bridge, Beijing, China) and incubated at $37^{\circ} \mathrm{C}$ for $24 \mathrm{~h}$. The $3 \mathrm{~mL}$ 
of culture was transferred to $300 \mathrm{~mL}$ of fresh TSB and incubated at $37^{\circ} \mathrm{C}$ to reach the stationary phase. The strain cultures were centrifugated $(4000 \times g$ for $10 \mathrm{~min})$ and the cell pellets were resuspended using $20 \mathrm{~mL}$ of phosphate buffer saline (PBS, $0.01 \mathrm{M}, \mathrm{pH} 7.2$ ), then centrifugated again and finally resuspended with $300 \mu \mathrm{L}$ of PBS to obtain a required concentration of $10^{10}-10^{11} \mathrm{CFU} / \mathrm{mL}$.

\subsection{Sample Preparation}

Tahini (fat $52.6 \%$, protein $26 \%$ and carbohydrate $15.7 \%$ ) was used in this study and the indigenous microbiota in tahini was less than $10^{2} \mathrm{CFU} / \mathrm{g}$, which did not interfere with the count of Salmonella cells grown on TSA. Diluted tahini $(50 \% w / w)$ was prepared by adding sterilized water, simulating common edible methods at home or restaurant in the Chinese diet [6].

Essential oils (EOs, Jiangxi Global Natural Spice Co., Ltd., Jiangxi, China) including oregano, cinnamon, thyme, tea tree, eucalyptus, peppermint, garlic and turmeric oils were directly added into undiluted and diluted tahini, obtaining the concentration of 1-3\%. $\varepsilon$-PL (BioDuly, Nanjing, China), tea-polyphenol (Macklin, Shanghai, China) and citric acid (CA, Huada, Guangdong, China) were dissolved or diluted to reach appropriate concentrations using sterilized water before adding to samples, obtaining the final concentration of $0.05-0.5 \%$ for organic acid and $0.05-0.4 \%$ for $\varepsilon-P L$ or tea-polyphenol. The $\mathrm{pH}$ values of samples were measured at room temperature using a $\mathrm{pH}$ meter (PHS-25; INESA, Shanghai, China).

\subsection{Thermal Treatment of S. montevideo CICC21588 in Undiluted or Diluted Tahini}

The thermal treatment was conducted using a heating block system (HBS) as described in a previous study [24]. About $0.8 \mathrm{~g}$ undiluted or diluted tahini was put into the sterile thermal death test (TDT) cells and $8 \mu \mathrm{L}$ of Salmonella suspension was inoculated on samples to achieve a cell density of about $10^{8}-10^{9} \mathrm{CFU} / \mathrm{mL}$. To study the Salmonella inactivation of EOs, $\varepsilon$-PL and organic acid during heating treatments, antimicrobials were added to the cells to obtain the target concentrations (oregano of $1-3 \%$, citric acid of $0.05-0.5 \%$ and $\varepsilon-\mathrm{PL}$ of $0.05-0.4 \%$ ). The $\mathrm{a}_{\mathrm{w}}$ of control group samples was adjusted by adding the same amount of deionized water as treated samples, but without antimicrobials.

Five TDT cells filled with $0.8 \mathrm{~g}$ inoculated samples were heated to the target temperatures $\left(75^{\circ} \mathrm{C}, 85^{\circ} \mathrm{C}\right.$ and $95^{\circ} \mathrm{C}$ for undiluted tahini; $56^{\circ} \mathrm{C}, 58^{\circ} \mathrm{C}$ and $60^{\circ} \mathrm{C}$ for diluted tahini) with a heating rate of $5^{\circ} \mathrm{C} / \mathrm{min}$ using $\mathrm{HBS}$, which was used to simulate the fast-heating rate in radio-frequency treated products. When the sample temperatures reached the target set-point, one cell was removed and defined as a time-zero sample. All the test cells were immediately cooled using ice-water after heat treatment.

\subsection{Oxford Cup Assay of Antimicrobials}

To study antibacterial effects of these natural antimicrobials against Salmonella of different serotypes rather than one specific serotype, Salmonella montevideo CICC21588, Salmonella typhimurium CMCC50115, Salmonella mbandaka NYS5-8 and Salmonella enteritidi R8-1-1 were used and compared. Antimicrobial activity of EOs, $\varepsilon-P L$, tea polyphenol and organic acid against Salmonella was determined by oxford cup assay (ID of $6 \mathrm{~mm}$ and OD of $8 \mathrm{~mm}$ ) according to Bian et al. [25] with some modifications. Briefly, oxford cups were put on the agar plates ( $2 \% w / v$ agar) and then TSB with $0.75 \%$ agar containing Salmonella $\left(10^{6} \mathrm{CFU} / \mathrm{mL}\right)$ was poured onto the plates and allowed to solidify. Afterwards, $100 \mu \mathrm{L}$ EOs or $200 \mu \mathrm{L}$ of two concentrations ( $5 \%$ and $10 \%)$ of $\varepsilon-\mathrm{PL}$, tea polyphenol and organic acid were added into the oxford cups. The plates were incubated at $37^{\circ} \mathrm{C}$ for $24 \mathrm{~h}$ and the inhibitory zone diameters were determined.

\subsection{Control of S. montevideo CICC21588 in Undiluted or Diluted Tahini by Antimicrobials}

Oregano oil was added to undiluted tahini to obtain the final concentrations of $1 \%$ and $3 \%(v / w)$. For water soluble antimicrobials, 20\% (w/v, clear solution) or $40 \%(w / v$, 
suspension) of $\varepsilon$-PL and $80 \%$ CA $(w / v)$ were added to undiluted tahini for obtaining final concentrations of $0.2 \%$ or $0.4 \%$, and $0.3 \%$ or $0.5 \%(w / w)$, respectively. The $\mathrm{a}_{\mathrm{w}}$ of control group samples was adjusted to the same with that of the treated samples. Afterwards, samples were inoculated with Salmonella suspension, obtaining a cell concentration of $10^{8}-10^{9} \mathrm{CFU} / \mathrm{g}$ and stored at $25^{\circ} \mathrm{C}$ or $4{ }^{\circ} \mathrm{C}$ for 7 days. S. montevideo CICC21588 populations in inoculated samples were enumerated after $0,1,2,3$ and 7 days.

Oregano oil was added to diluted tahini to obtain final concentrations of $1-3 \%(v / w)$. For water soluble antimicrobials, 20\% $\varepsilon$-PL $(w / v)$ and 20\% CA $(w / v)$ were added to diluted tahini to obtain final concentrations of $0.05-0.5 \%(w / w)$. Then samples were inoculated with Salmonella suspension, obtaining a cell concentration of $10^{6} \mathrm{CFU} / \mathrm{g}$ and stored at $25^{\circ} \mathrm{C}$ or $4{ }^{\circ} \mathrm{C}$ for 7 days. Bacterial enumeration was conducted at $0 \mathrm{~h}, 4 \mathrm{~h}, 7 \mathrm{~h}, 11 \mathrm{~h}, 14 \mathrm{~h}, 24 \mathrm{~h}$, $36 \mathrm{~h}, 52 \mathrm{~h}$ and $72 \mathrm{~h}$ and after 7 days.

\subsection{Bacterial Enumeration}

After the treatment, each sample was transferred into a sterile tube, diluted using 9 times sterile PBS and shaken for $1 \mathrm{~min}$. The suspension was serially diluted 10 -fold in sterile PBS and $0.1 \mathrm{~mL}$ of diluent was spread onto TSA, and incubated at $37{ }^{\circ} \mathrm{C}$ for $24-48 \mathrm{~h}$ until the colonies were formed. To evaluate the sublethal injured cells, xylose lysine deoxycholate (XLD, Hopebio, Qingdao, China) agar plate [26] and TSA plate containing $4 \% \mathrm{NaCl}$ (TSA-NaCl) [27] were used. XLD containing $0.25 \%$ deoxycholate and TSA with $4 \% \mathrm{NaCl}$ (TSA-NaCl) plates have been used to evaluate outer membrane damage and cytoplasmic membrane damage of Salmonella, respectively [28], because cells with membrane damages cannot grow on XLD and TSA-NaCl plates but grow on TSA. However, this method could only roughly reflect sublethal cell level but was not completely accurate, because some cells with small damage could still grow on the selective medium.

\subsection{Modeling of Thermal Inactivation Kinetics}

The first-order kinetic and Weibull distribution models were used to fit the thermal inactivation data. The first-order kinetic model was defined by the following equation:

$$
\log S(t) \frac{N}{N_{0}}=-\frac{t}{D}
$$

where $S(t)$ is the survival ratio, $N(\mathrm{CFU} / \mathrm{g})$ represents the bacteria population at the time $t$ (min) of isothermal treatment, $N_{0}(\mathrm{CFU} / \mathrm{g})$ represents the bacteria population at the time reaching the target temperature and $\mathrm{D}$ is the decimal reduction time $(\mathrm{min})$ at temperature $\mathrm{T}\left({ }^{\circ} \mathrm{C}\right)$.

The Weibull model can be expressed as:

$$
\log S(t)=-\left(\frac{t}{\delta}\right)^{p}
$$

where $\delta$ is scale parameter and $p$ is shape parameter, indicating the survival curve's concavity. $p=1,<1$ and $>1$ represent liner, concave-upward (tailing) and concave-downward (shoulder) inactivation curves, respectively. For both the first-order kinetic and the Weibull distribution models, the coefficient of determination $\left(\mathrm{R}^{2}\right)$ reflects the goodness of fit.

\subsection{Statistical Analysis}

All treatments were conducted in triplicate. The statistical significance of differences was evaluated by a one-way analysis of variance (ANOVA) and the Duncan post-hoc test ( $p=0.05)$ using the SPSS statistics 17.0 software (SPSS Inc., Chicago, IL, USA). The parameters for the first-order kinetic and Weibull distribution models were obtained using the SPSS Statistics 17.0. 


\section{Results and Discussion}

\subsection{Thermal Inactivation of S. montevideo CICC21588 in Undiluted or Diluted Tahini}

S. montevideo CICC21588 was selected to be further used in tahini samples due to its most desiccation and thermal resistance in undiluted tahini among four strains of serotypes according to results of pre-experiments (data not shown). The thermal inactivation curves of S. montevideo CICC21588 in undiluted or diluted tahini with a heating rate of $5^{\circ} \mathrm{C} / \mathrm{min}$ in the HBS under different temperatures are shown in Figure 2. D-, $\delta$ - and $p$-values obtained from first-order kinetic and Weibull distribution models for describing the thermal inactivation behavior are listed in Table 1 . The larger coefficient of determination $\left(R^{2}=0.973-0.996\right)$ and lower root mean square deviation (RMSE $=0.078-0.279$ ) of the Weibull model compared to those $\left(R^{2}=0.775-0.906\right.$, RMSE $\left.=0.435-0.913\right)$ of the first-order kinetic model indicated that the Weibull model was more suitable to describe the thermal inactivation behavior of $S$. montevideo CICC21588 in undiluted and diluted tahini. In undiluted tahini, $\delta$-values were $10.6,5.21$ and 3.84 at $75{ }^{\circ} \mathrm{C}, 85^{\circ} \mathrm{C}$ and $95^{\circ} \mathrm{C}$, respectively. The high thermal resistance of Salmonella was reported in undiluted sample due to its extremely low $\mathrm{a}_{\mathrm{w}}$ (0.256) and high fat content (52.6\%). He et al. [29] also found minimum times to achieve 1-log reduction of $S$. enterica serotypes in peanut butter $\left(\mathrm{a}_{\mathrm{w}} 0.2\right.$, fat $\left.49 \%\right)$ at $90{ }^{\circ} \mathrm{C}$ were 6.32-12.08 min based on the Weibull model. Krapf and Gantenbein-Demarchi [30] studied the thermal inactivation of Salmonella in dark chocolate $\left(\mathrm{a}_{\mathrm{w}} 0.3-0.5\right.$, fat $\left.\geq 18 \%\right)$ and found that the D-value at $90^{\circ} \mathrm{C}$ was $25 \mathrm{~min}$. In diluted tahini, $\delta$-values were $16.52,4.38$ and 0.92 at $56^{\circ} \mathrm{C}, 58{ }^{\circ} \mathrm{C}$ and $60^{\circ} \mathrm{C}$, respectively. $\delta$-value decreased with the increase of temperature and $\mathrm{a}_{\mathrm{w}}$, similar to results obtained by Gautam, Govindan, Gänzle and Roopesh [31].
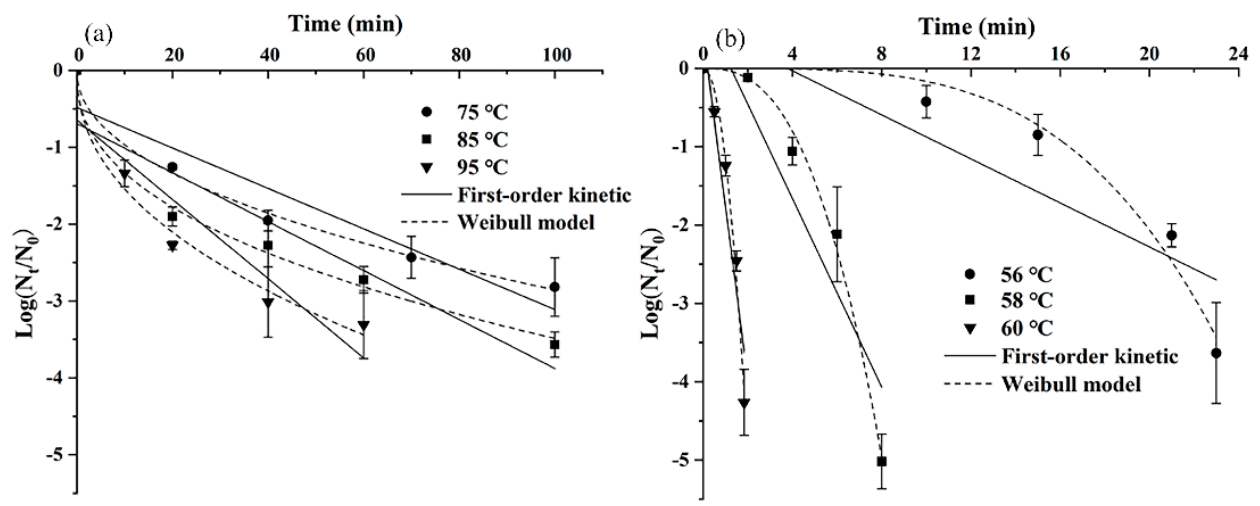

Figure 2. Thermal inactivation kinetics of $S$. montevideo CICC21588 in undiluted $\left(\mathrm{a}_{\mathrm{w}}=0.256\right)(\mathbf{a})$ and diluted tahini $\left(\mathrm{a}_{\mathrm{w}}=1.000\right)(\mathbf{b})$ at different temperatures.

Table 1. Fitted $D$-values of the first-order kinetic model and $\delta$ - and $p$-values of the Weibull model for thermal inactivation of S. Montevideo CICC21588 inoculated into undiluted or diluted tahini at different temperatures with heating rate of $5{ }^{\circ} \mathrm{C} / \mathrm{min}$ using TDT HBS.

\begin{tabular}{|c|c|c|c|c|c|c|c|c|c|c|}
\hline \multirow{2}{*}{ Samples } & \multirow{2}{*}{$\begin{array}{c}\text { Moisture } \\
\text { Content (\%) }\end{array}$} & \multirow{2}{*}{$a_{w}$} & \multirow{2}{*}{$\begin{array}{c}\text { Temperature } \\
\left({ }^{\circ} \mathrm{C}\right)\end{array}$} & \multicolumn{3}{|c|}{ First-Order Model } & \multicolumn{4}{|c|}{ Weibull Model } \\
\hline & & & & $D$ (min) & $\mathbf{R}^{2}$ & RMSE & $\delta$ & $p$ & $R^{2}$ & RMSE \\
\hline \multirow{3}{*}{$\begin{array}{l}\text { Undiluted } \\
\text { tahini }\end{array}$} & \multirow{3}{*}{$0.629 \pm 0.001$} & \multirow{3}{*}{$0.256 \pm 0.002$} & 75 & $38.43 \pm 4.62$ & 0.885 & 0.435 & $10.65 \pm 1.18$ & $0.47 \pm 0.07$ & 0.996 & 0.078 \\
\hline & & & 85 & $31.43 \pm 1.41$ & 0.856 & 0.581 & $5.21 \pm 1.71$ & $0.42 \pm 0.04$ & 0.994 & 0.114 \\
\hline & & & 95 & $19.66 \pm 2.74$ & 0.851 & 0.601 & $3.84 \pm 0.67$ & $0.45 \pm 0.05$ & 0.985 & 0.190 \\
\hline \multirow{3}{*}{$\begin{array}{l}\text { Diluted } \\
\text { tahini }\end{array}$} & \multirow{3}{*}{$50.240 \pm 1.290$} & \multirow{3}{*}{$1.000 \pm 0.000$} & 56 & $7.17 \pm 0.76$ & 0.775 & 0.810 & $16.52 \pm 1.42$ & $3.91 \pm 1.21$ & 0.973 & 0.279 \\
\hline & & & 58 & $1.67 \pm 0.17$ & 0.853 & 0.913 & $4.38 \pm 0.52$ & $2.70 \pm 0.48$ & 0.993 & 0.195 \\
\hline & & & 60 & $0.46 \pm 0.04$ & 0.906 & 0.602 & $0.92 \pm 0.08$ & $2.09 \pm 0.39$ & 0.985 & 0.237 \\
\hline
\end{tabular}

In undiluted tahini $\left(\mathrm{a}_{\mathrm{w}}=0.256\right), p$-values of the Weibull model were less than one under three thermal treatments of $75^{\circ} \mathrm{C}, 85^{\circ} \mathrm{C}$ and $95^{\circ} \mathrm{C}$. The inactivation curves were concave-upward, as shown in Figure $2 \mathrm{a}$, in accordance with previous reports, such as 
thermal inactivation of Salmonella in peanut butter [32], black peppercorns, pecans, almonds [33] and pet food pellets [31]. According to these reports, thermal inactivation curves of pathogens in low moisture foods (LMFs) usually exhibit concave-upward, indicating that pathogens are inactivated directly without a large damage accumulation and the survival populations become increasingly resistant to thermal stress.

As shown in Figure $2 b$, a shoulder was observed for the inactivation curves of 5 . montevideo CICC21588 in diluted tahini by heating at $56{ }^{\circ} \mathrm{C}, 58{ }^{\circ} \mathrm{C}$ and $60^{\circ} \mathrm{C}$. The concavedownward thermal inactivation curves also appear in foods with high water content, such as Salmonella inactivation in whole liquid egg [34], Escherichia coli O157:H7 inactivation in orange juice [35] or apple juice [28] and Listeria monocytogenes inactivation in semi-skim milk [36]. These results indicated that bacteria cells were firstly resistant to the sublethal temperatures but continuous heating made the injured cells difficult to survive.

\subsection{The Sublethal Injured Cells in Thermal Treatments in Undiluted and Diluted Tahini}

Figure 3 presents the levels of sublethal injured S. montevideo CICC21588 cells in undiluted or diluted tahini by thermal treatments. For undiluted tahini, as shown in Figure 3A-C, statistically significant differences of the population grown on the TSA, XLD and TSA- $\mathrm{NaCl}$ were only observed at the thermal treatments of $75{ }^{\circ} \mathrm{C}$ for $0 \mathrm{~min}$ and $95{ }^{\circ} \mathrm{C}$ for $0 \mathrm{~min}(p<0.05)$, indicating that cell membrane damages occurred under these treatments. However, the injured cell populations were less than $1 \log \mathrm{CFU} / \mathrm{g}$. The similar result was also obtained by Lee et al. [37], who found that steam treatment $\left(93^{\circ} \mathrm{C}\right)$ inactivated Salmonella enteritidis on the raw shelled almonds without causing significant sublethal injury.
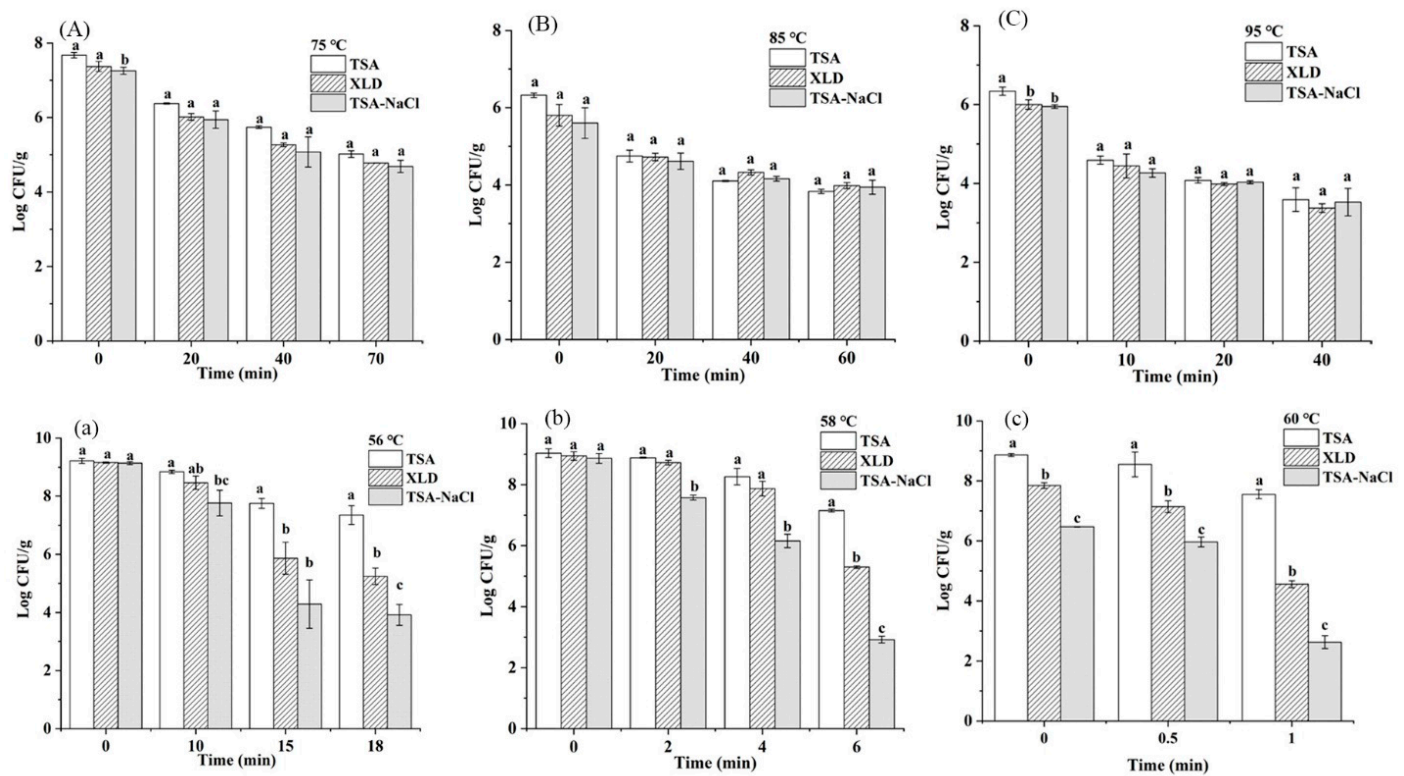

Figure 3. Population of S. montevideo CICC21588 in undiluted tahini (A-C) and diluted tahini (a-c) grown on TSA, XLD and TSA- $\mathrm{NaCl}$ plates at different treatment temperatures. The same low case letter among different plates at each treatment indicates values are not significantly different $(p>0.05)$.

For diluted tahini, a large number of injured cells were produced under the thermal treatments of $56^{\circ} \mathrm{C}, 58^{\circ} \mathrm{C}$ and $60^{\circ} \mathrm{C}$, as shown in Figure $3 \mathrm{a}-\mathrm{c}$. The heat treatments of $56^{\circ} \mathrm{C}$ for $18 \mathrm{~min}, 58^{\circ} \mathrm{C}$ for $6 \mathrm{~min}$ and $60^{\circ} \mathrm{C}$ for $1 \mathrm{~min}$ caused more than $3 \log \mathrm{CFU} / \mathrm{g}$ injured cells. In addition, the lower population grown on the TSA-NaCl than on the XLD after three temperature treatments for each time indicated that the thermal stress caused more damage to cytoplasmic membrane than outer membrane of S. montevideo CICC21588. It has been reported that a mild thermal stress $\left(54-60^{\circ} \mathrm{C}\right)$ causes a large number of injured cells of Escherichia coli O157:H7 in fruit juice, however, more outer membrane damages are 
observed than cytoplasmic membrane damages, which is inconsistent with the results in this study possibly due to the different strain used [28,35].

That more sublethal injured cells caused by thermal stress in diluted tahini than in undiluted tahini corresponds to the thermal inactivation curves as described in Section 3.1, S. montevideo CICC21588 populations were inactivated directly by relatively high temperatures in undiluted tahini without causing significant injured cells and curves were concave-upward. While in diluted tahini, a damage accumulation was observed at the beginning of heating and the inactivation curves were concave-downward.

\subsection{Inhibitory Activity against Salmonella of EOs, $\varepsilon-P L$, Tea Polyphenol or Organic Acid}

Tables 2 and 3 show the inhibitory activity against Salmonella of EOs, $\varepsilon$-PL, tea polyphenol and organic acid using the oxford cup assay. For EOs, as listed in Table 2, tea tree, eucalyptus, peppermint, garlic and turmeric oils exhibited less inhibitory activity or even no effect against four Salmonella serotypes compared to oregano, cinnamon and thyme oils. Furthermore, oregano oil exhibited the strongest antimicrobial activity with inhibition zones of $21.38-24.00 \mathrm{~mm}$.

For water-soluble antimicrobial agents, as presented in Table $3, \varepsilon$-PL and tea polyphenol also had the inhibitory activity against Salmonella with inhibition zones of $16.25-23.50 \mathrm{~mm}$ and $13.00-18.50 \mathrm{~mm}$ at the concentration of $10 \%$, respectively.

Organic acids, such as citric acid and lactic acid, are widely used in the food industry to control pathogens or regulate acid flavor, generally regarded as safe [38]. From Table 3, citric acid and lactic acid both exhibited significant inhibitory effect against Salmonella with inhibition zones of $25.75-27.70 \mathrm{~mm}$ and $24.00-27.20 \mathrm{~mm}$ at the concentration of $10 \%$, respectively. The antimicrobials effect of lactic acid was slightly smaller than that of the citric acid. Therefore, oregano oil, $\varepsilon-\mathrm{PL}$, tea polyphenol and CA were further selected to control S. montevideo CICC21588 in undiluted and diluted tahini according to the inhibition zones.

\subsection{Effect of Oregano Oil, $\varepsilon-P L$ and CA on the Viability of S. Montevideo CICC21588 in Undiluted and Diluted Tahini}

As shown in Figure 4a, S. montevideo CICC21588 population was significantly reduced by $3.61 \log \mathrm{CFU} / \mathrm{g}$ in undiluted tahini with $3 \%$ oregano oil after 7 days at $25^{\circ} \mathrm{C}$, compared to $2.17 \log \mathrm{CFU} / \mathrm{g}$ in the control $(p<0.05)$. After 7 days at $4{ }^{\circ} \mathrm{C}, 1.53$ and $1.47 \log \mathrm{CFU} / \mathrm{g}$ reductions were observed in undiluted tahini with $1 \%$ and $3 \%$ oregano oil, respectively, compared to $0.67 \log \mathrm{CFU} / \mathrm{g}$ in the control $(p<0.05)$. This result indicated that $3 \%$ oregano oil could effectively inactivate Salmonella in undiluted tahini without bringing water into samples, causing no influence on its shelf life. However, $3 \%$ oregano oil influenced the flavor of tahini and might not be accepted by consumers.

In addition, results showed that the Salmonella population in undiluted tahini declined faster at higher temperatures during the storage period of $7 \mathrm{~d}$, in accordance with previous research related to LMFs [39]. Park, Oh and Kang [40] found that the survival of $S$. Tennessee cells in peanut butter was significantly lower at $22{ }^{\circ} \mathrm{C}$, compared to $4{ }^{\circ} \mathrm{C}$ during the storage period of $14 \mathrm{~d}$. The possible reason probably is that the metabolism of bacteria at the relatively low temperature is lower than that in the high temperature, which helps Salmonella to maintain biological activity. 
Table 2. Antimicrobial activity of EOs against 4 Salmonella strains using the oxford cup assay.

\begin{tabular}{|c|c|c|c|c|c|c|c|c|c|}
\hline \multirow{2}{*}{ Foodborne Pathogens } & \multicolumn{9}{|c|}{ Essential Oils (EOs) } \\
\hline & Oregano & Cinnamon & Thyme & Tea tree & Eucalyptus & Peppermint & Garlic & Turmeric & Control \\
\hline S. montevideo CICC 21588 & $23.42 \pm 1.02^{\mathrm{a}}$ & $22.58 \pm 0.92^{a}$ & $16.28 \pm 0.66^{b}$ & $12.50 \pm 0.41^{c}$ & $8.75 \pm 0.35^{\mathrm{d}}$ & $8.00 \pm 0.00^{\mathrm{d}}$ & $8.00 \pm 0.00^{d}$ & $8.00 \pm 0.00^{d}$ & $8.00 \pm 0.00^{d}$ \\
\hline S. Typhimurium CMCC50115 & $24.00 \pm 0.41^{\mathrm{a}}$ & $22.00 \pm 0.41^{b}$ & $20.63 \pm 0.48^{c}$ & $14.38 \pm 0.48^{\mathrm{e}}$ & $15.25 \pm 0.65^{\mathrm{d}}$ & $8.83 \pm 0.29 \mathrm{~g}$ & $9.76 \pm 0.35^{\mathrm{f}}$ & $8.00 \pm 0.00^{h}$ & $8.00 \pm 0.00^{h}$ \\
\hline S. Mbandaka NYS5-8 & $21.38 \pm 0.48^{\mathrm{a}}$ & $19.88 \pm 0.75^{b}$ & $17.38 \pm 0.48^{c}$ & $13.00 \pm 0.00^{\mathrm{d}}$ & $11.00 \pm 0.00^{\mathrm{e}}$ & $8.00 \pm 0.00 \mathrm{~g}$ & $9.25 \pm 0.35^{f}$ & $8.00 \pm 0.00 \mathrm{~g}$ & $8.00 \pm 0.00 \mathrm{~g}$ \\
\hline S. enteritidis R8-1-1 & $22.38 \pm 0.48^{a}$ & $22.75 \pm 0.65^{\mathrm{a}}$ & $16.00 \pm 0.41^{b}$ & $14.25 \pm 0.29^{c}$ & $11.00 \pm 0.00^{\mathrm{d}}$ & $8.00 \pm 0.00^{\mathrm{e}}$ & $8.00 \pm 0.00^{\mathrm{e}}$ & $8.00 \pm 0.00^{\mathrm{e}}$ & $8.00 \pm 0.00^{\mathrm{e}}$ \\
\hline
\end{tabular}

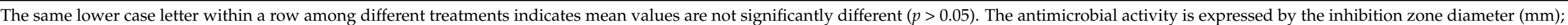

the additive amount is $100 \mu \mathrm{L}$ essential oils/cup.

Table 3. Antimicrobial activity of $\varepsilon-\mathrm{PL}$, tea polyphenol, citric acid and lactic acid against 4 Salmonella strains using the oxford cup assay.

\begin{tabular}{|c|c|c|c|c|c|c|c|c|c|}
\hline \multirow{2}{*}{ Foodborne Pathogens } & \multirow{2}{*}{ Control } & \multicolumn{2}{|c|}{$\varepsilon$-PL } & \multicolumn{2}{|c|}{ Tea Polyphenol } & \multicolumn{2}{|c|}{ Citric Acid } & \multicolumn{2}{|c|}{ Lactic Acid } \\
\hline & & $10 \%$ & $5 \%$ & $10 \%$ & $5 \%$ & $10 \%$ & $5 \%$ & $10 \%$ & $5 \%$ \\
\hline S. montevideo CICC21588 & $8.00 \pm 0.00^{f}$ & $23.50 \pm 0.71^{\mathrm{c}}$ & $20.50 \pm 0.71^{d}$ & $11.38 \pm 0.75^{\mathrm{e}}$ & $8.00 \pm 0.00^{f}$ & $27.61 \pm 0.48^{a}$ & $23.13 \pm 0.85^{c}$ & $26.08 \pm 0.38^{b}$ & $21.00 \pm 0.41^{\mathrm{c}}$ \\
\hline S. Typhimurium CMCC50115 & $8.00 \pm 0.00^{\mathrm{f}}$ & $17.50 \pm 0.50^{\mathrm{d}}$ & $12.75 \pm 0.65^{\mathrm{e}}$ & $18.50 \pm 0.71^{\mathrm{d}}$ & $13.33 \pm 0.58^{\mathrm{e}}$ & $25.75 \pm 1.19^{\mathrm{a}}$ & $21.38 \pm 0.48^{c}$ & $24.63 \pm 0.48^{b}$ & $20.38 \pm 0.48$ \\
\hline S. Mbandaka NYS5-8 & $8.00 \pm 0.00^{h}$ & $16.25 \pm 0.35^{\mathrm{e}}$ & $11.50 \pm 0.71 \mathrm{~g}$ & $14.75 \pm 0.35^{\mathrm{f}}$ & $11.75 \pm 0.35 \mathrm{~g}$ & $26.50 \pm 0.50^{a}$ & $22.25 \pm 0.50^{\mathrm{c}}$ & $24.00 \pm 0.41^{b}$ & $17.75 \pm 0.29^{\mathrm{c}}$ \\
\hline S. enteritidis R8-1-1 & $8.00 \pm 0.00^{f}$ & $18.13 \pm 0.63^{c}$ & $15.00 \pm 0.41^{d}$ & $13.00 \pm 1.47^{\mathrm{e}}$ & $8.00 \pm 0.00^{f}$ & $27.70 \pm 0.68^{a}$ & $24.09 \pm 0.33^{b}$ & $27.20 \pm 0.53^{a}$ & $23.68 \pm 0.35^{b}$ \\
\hline
\end{tabular}

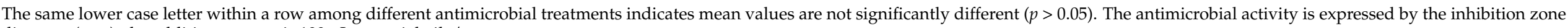
diameter (mm); the additive amount is $100 \mu \mathrm{L}$ essential oils/cup. 

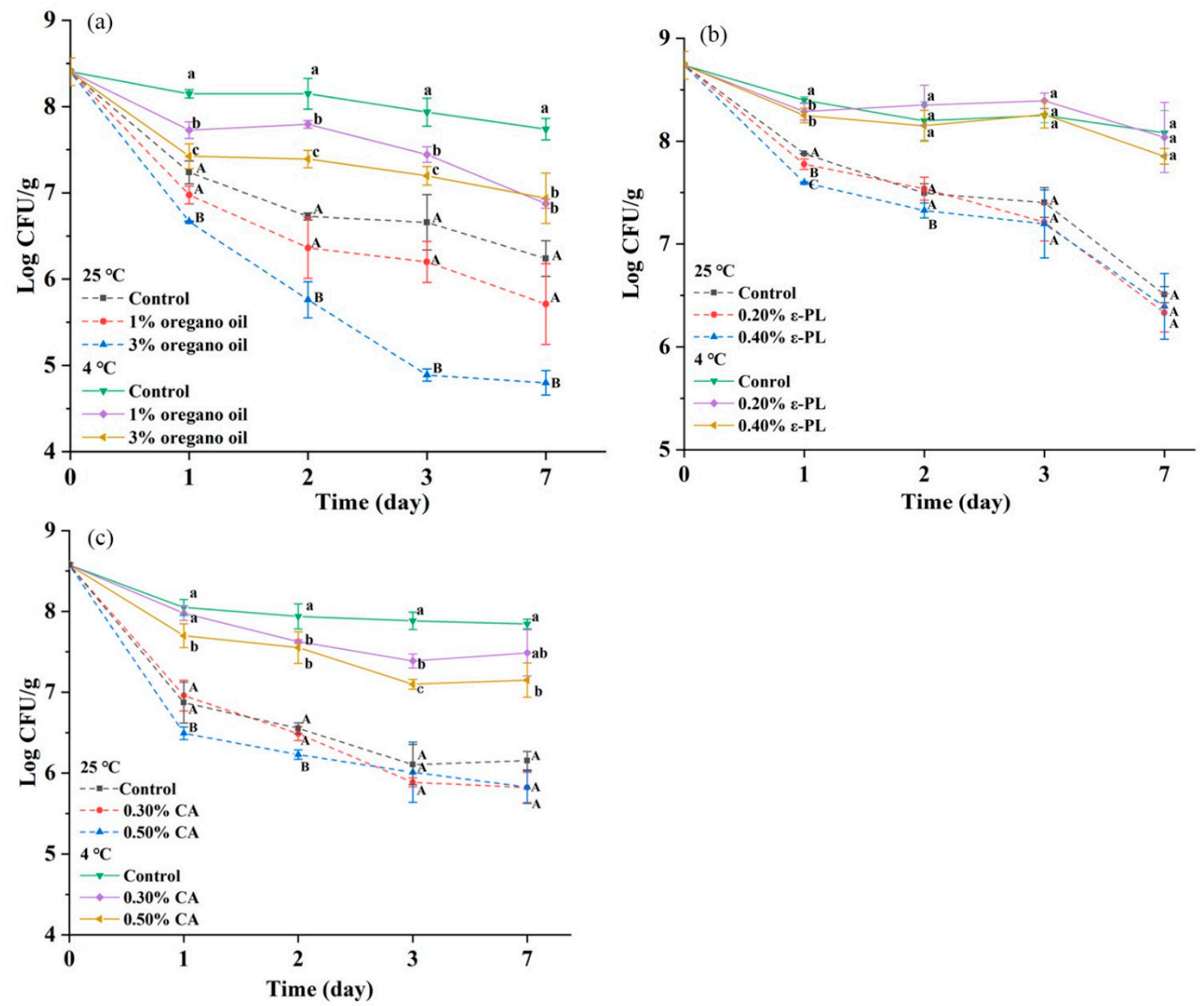

Figure 4. Antimicrobial activity of oregano oil (a), $\varepsilon$-PL (b) and CA (c) against S. montevideo CICC 21588 in undiluted tahini at $25^{\circ} \mathrm{C}$ or $4{ }^{\circ} \mathrm{C}$. The same lower case letter among different treated samples at each day during $4{ }^{\circ} \mathrm{C}$ storage indicates mean values are not significantly different $(p>0.05)$. The same uppercase letter among different treated samples at each day during $25^{\circ} \mathrm{C}$ storage indicates values are not significantly different $(p>0.05)$.

The addition of $\varepsilon$-PL and CA may bring water into undiluted tahini, which might accelerate the oxidative rancidity of fat, influencing its shelf life. Therefore, it is necessary to ensure the original concentrations of $\varepsilon$-PL and CA high. From Figure 4c, $0.2-0.4 \% \varepsilon-\mathrm{PL}$ had no effect on the Salmonella reduction during the storage period of 7 days at $4{ }^{\circ} \mathrm{C}$ or $25^{\circ} \mathrm{C}(p>0.05)$. A reduction of $1.42 \log \mathrm{CFU} / \mathrm{g}$ was observed in undiluted tahini with $0.5 \%$ CA after 7 days at $4{ }^{\circ} \mathrm{C}$, compared to the control of $0.73 \log \mathrm{CFU} / \mathrm{g}(p<0.05)$. This result indicated that $0.5 \%$ CA only caused less than $1 \log \mathrm{CFU} / \mathrm{g}$ extra reduction compared to the control after 7 days of storage period. Although Al-Nabulsi et al. [41] have found more pronounced bactericidal effect against Salmonella typhimurium in undiluted tahini by CA compared to our results, but the amount of water brought into tahini is not shown in their study, which would influence the bactericidal effect.

The inhibitory effects of oregano oil, $\varepsilon-\mathrm{PL}$ and CA against S. montevideo CICC21588 in diluted tahini during the storage period of 7 days at $4{ }^{\circ} \mathrm{C}$ or $25^{\circ} \mathrm{C}$ are shown in Figure 5 and Table 4. At $25^{\circ} \mathrm{C}$, the bacteria grown from $6.19 \mathrm{log} \mathrm{CFU} / \mathrm{g}$ up to the maximum population of $9.30 \log \mathrm{CFU} / \mathrm{g}$ at $24 \mathrm{~h}$, then slightly decreased to $8.63 \mathrm{log} \mathrm{CFU} / \mathrm{g}$ at $52 \mathrm{~h}$ and $8.70 \log \mathrm{CFU} / \mathrm{g}$ at $72 \mathrm{~h}$ in diluted tahini without any antimicrobials, indicating that $50 \%$ 
$(w / w)$ diluted tahini provided a suitable environment for Salmonella growth, posing a great threat to consumer health. After 7 days at $25^{\circ} \mathrm{C}$, samples without antimicrobials suffered deterioration caused by Bacillus subtilis originally existed in tahini (characterized by $16 \mathrm{~S}$ rRNA gene sequencing), influencing the Salmonella enumeration. During the storage period of 7 days at $4{ }^{\circ} \mathrm{C}$, S. montevideo CICC21588 population remained stable, about $6.19-6.40 \log$ $\mathrm{CFU} / \mathrm{g}$ in diluted tahini without antimicrobials.
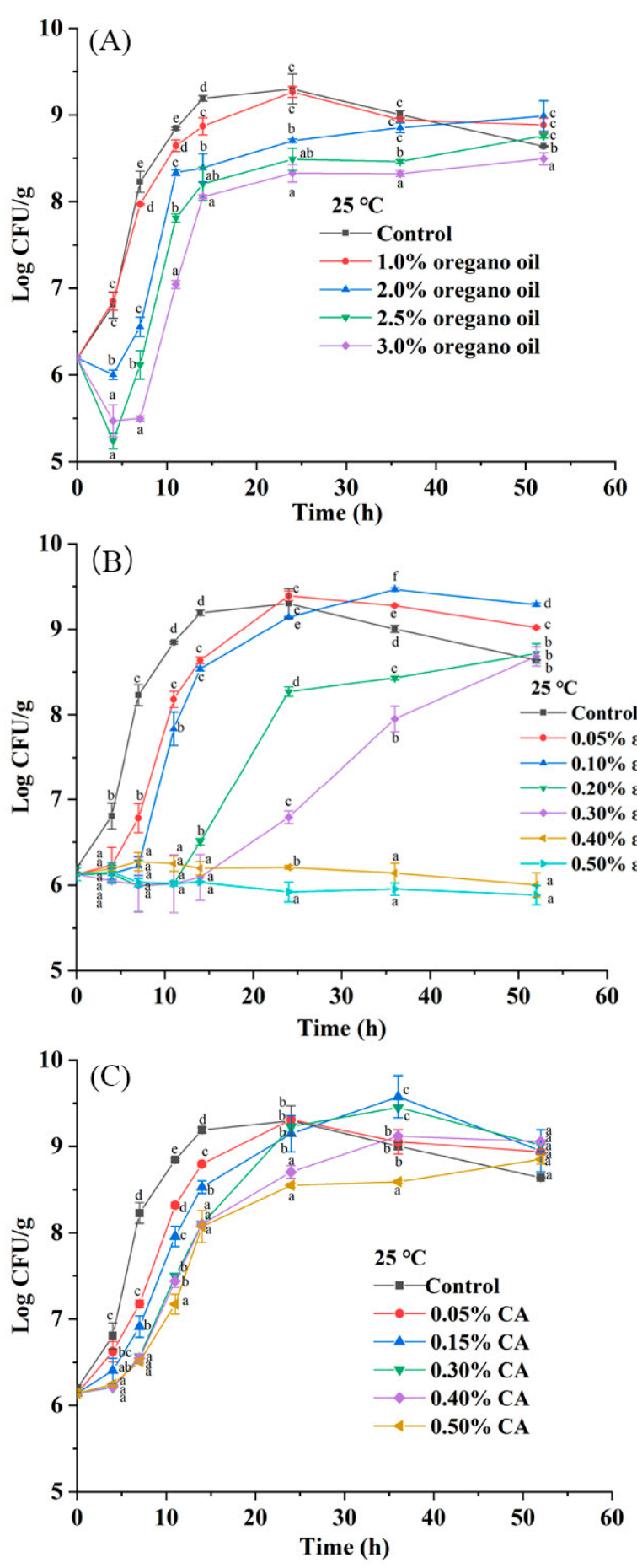
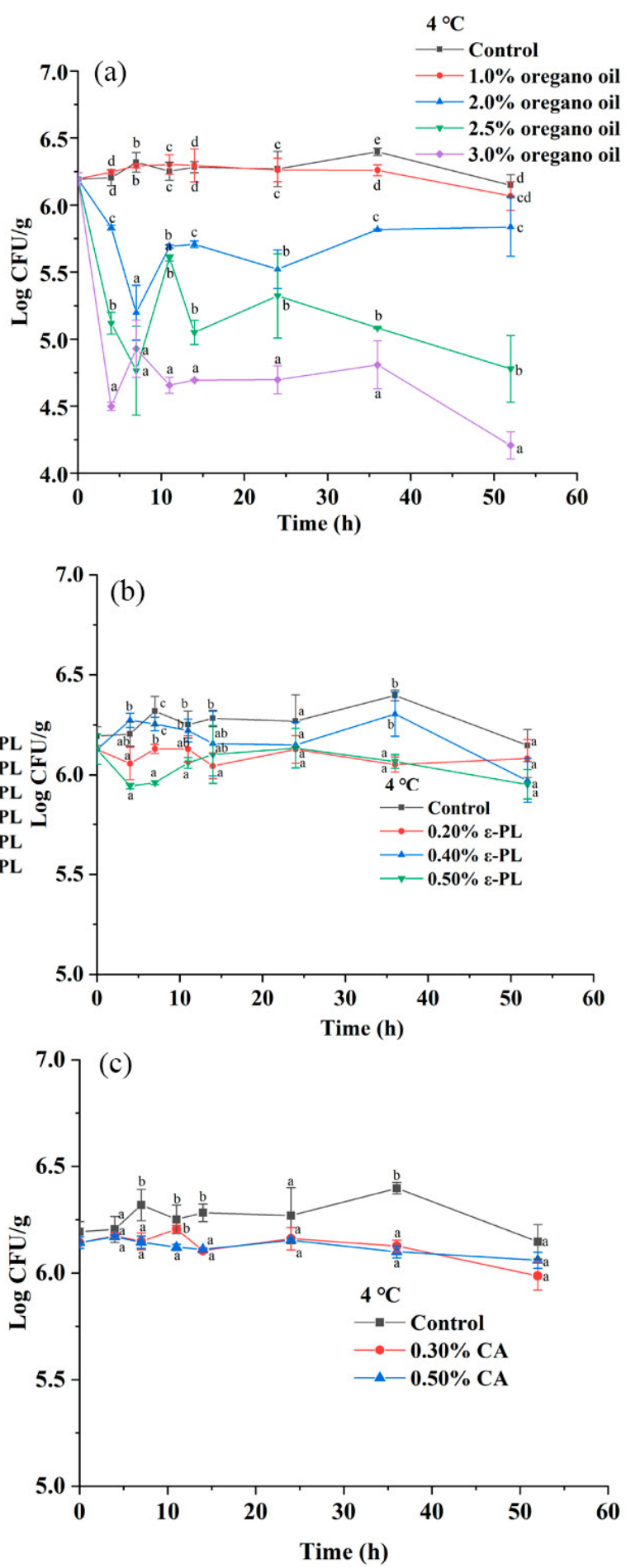

Figure 5. Antimicrobial activity of oregano oil, $\varepsilon$-PL and CA against $S$. montevideo CICC21588 in diluted tahini at $25^{\circ} \mathrm{C}(\mathbf{A}-\mathrm{C})$ or $4{ }^{\circ} \mathrm{C}(\mathbf{a}-\mathbf{c})$. The same lower case letter among different treated samples at each day during storage indicates mean values that are not significantly different $(p>0.05)$. 
Table 4. Antimicrobial activity of oregano oil, $\varepsilon$-PL and CA against S. montevideo CICC 21588 in diluted tahini at $25^{\circ} \mathrm{C}$ or $4{ }^{\circ} \mathrm{C}$.

\begin{tabular}{|c|c|c|c|c|c|c|c|c|c|c|}
\hline \multirow{2}{*}{\multicolumn{2}{|c|}{ Antimicrobials }} & \multirow{3}{*}{$\begin{array}{c}\text { Day } 0 \\
19 \pm 0.05^{a}\end{array}$} & \multicolumn{4}{|c|}{$25^{\circ} \mathrm{C}$} & \multicolumn{4}{|c|}{$4{ }^{\circ} \mathrm{C}$} \\
\hline & & & \multirow{2}{*}{$\frac{1}{9.30 \pm 0.17^{\mathrm{a}}}$} & \multirow{2}{*}{$\begin{array}{c}\mathbf{2}(\mathbf{5 2} \mathbf{h}) \\
8.64 \pm 0.01^{\mathrm{cd}}\end{array}$} & \multirow{2}{*}{$\frac{3}{8.70 \pm 0.14^{a b c}}$} & \multirow{2}{*}{$\begin{array}{c}7 \\
D E\end{array}$} & \multirow{2}{*}{$\frac{1}{6.27 \pm 0.13^{\mathrm{a}}}$} & \multirow{2}{*}{$\frac{2 \text { (52 h) }}{6.15 \pm 0.08^{a}}$} & \multirow{2}{*}{$\frac{3}{6.14 \pm 0.08^{\mathrm{a}}}$} & \multirow{2}{*}{$\frac{7}{6.22 \pm 0.19^{a}}$} \\
\hline Control & $0 \%$ & & & & & & & & & \\
\hline \multirow[t]{2}{*}{ Oregano oil } & $2 \%$ & $6.19 \pm 0.05^{a}$ & $8.70 \pm 0.02^{b}$ & $8.99 \pm 0.17^{\mathrm{a}}$ & $8.93 \pm 0.04^{a b}$ & $8.44 \pm 0.06^{c}$ & $5.52 \pm 0.14^{b}$ & $5.84 \pm 0.22^{b}$ & $5.99 \pm 0.02^{\mathrm{ab}}$ & $5.50 \pm 0.40^{b}$ \\
\hline & $3 \%$ & $6.19 \pm 0.05^{\mathrm{a}}$ & $8.33 \pm 0.10^{c}$ & $8.49 \pm 0.07^{\mathrm{d}}$ & $8.67 \pm 0.36^{a b c}$ & $8.74 \pm 0.04^{b}$ & $4.70 \pm 0.10^{c}$ & $4.21 \pm 0.10^{c}$ & $4.18 \pm 0.32^{c}$ & $2.63 \pm 0.46^{\mathrm{e}}$ \\
\hline \multirow{2}{*}{$\varepsilon-P L$} & $0.2 \%$ & $6.13 \pm 0.08^{a}$ & $8.27 \pm 0.06^{c}$ & $8.72 \pm 0.12^{b c}$ & $8.95 \pm 0.13^{a}$ & $9.36 \pm 0.004^{a}$ & $6.13 \pm 0.07^{a}$ & $6.08 \pm 0.10^{\mathrm{a}}$ & $6.04 \pm 0.03^{a b}$ & $6.02 \pm 0.11^{a}$ \\
\hline & $0.5 \%$ & $6.13 \pm 0.08^{a}$ & $5.92 \pm 0.11^{\mathrm{e}}$ & $5.88 \pm 0.11^{\mathrm{e}}$ & $6.16 \pm 0.06^{\mathrm{e}}$ & $9.31 \pm 0.04^{\mathrm{a}}$ & $6.13 \pm 0.10^{a}$ & $5.95 \pm 0.08^{\mathrm{ab}}$ & $5.88 \pm 0.06^{\mathrm{b}}$ & $3.68 \pm 0.59^{d}$ \\
\hline \multirow{2}{*}{ CA } & $0.3 \%$ & $6.14 \pm 0.03^{a}$ & $9.23 \pm 0.03^{a}$ & $9.02 \pm 0.06^{\mathrm{a}}$ & $8.44 \pm 0.07^{c}$ & $\mathrm{DE}$ & $6.16 \pm 0.05^{\mathrm{a}}$ & $5.99 \pm 0.07^{\mathrm{ab}}$ & $6.14 \pm 0.11^{a}$ & $6.03 \pm 0.11^{a}$ \\
\hline & $0.5 \%$ & $6.14 \pm 0.03^{\mathrm{a}}$ & $8.55 \pm 0.03^{b}$ & $8.85 \pm 0.05^{\mathrm{abc}}$ & $8.57 \pm 0.04^{a b c}$ & $\mathrm{DE}$ & $6.15 \pm 0.01^{\mathrm{a}}$ & $6.06 \pm 0.04^{\mathrm{a}}$ & $6.12 \pm 0.10^{\mathrm{a}}$ & $6.04 \pm 0.15^{\mathrm{a}}$ \\
\hline
\end{tabular}

The same lower case letter with a column among different antimicrobial treatments indicates mean values are not significantly different ( $p>0.05)$. DE means samples suffered deterioration. 
As shown in Figure 5A and Table 4, the addition of $2-3 \%$ oregano oil to diluted tahini slowed down the growth of S. montevideo CICC21588 and slightly reduced the population at $4 \mathrm{~h}$. $3 \%$ oregano oil could inhibit the growth up to $7 \mathrm{~h}$. After 2 or 3 days at $25^{\circ} \mathrm{C}$, the population reached levels of 8.99 or $8.67 \log \mathrm{CFU} / \mathrm{g}$ with $2 \%$ and $3 \%$ oregano oil, respectively. While after 7 days at $4{ }^{\circ} \mathrm{C}, 2-3 \%$ oregano oil significantly reduced $S$. montevideo CICC 21588 population by $0.70-3.57 \log$ CFU/g $(p<0.05)$ as listed in Table 4. Furthermore, diluted tahini samples with 1-3\% oregano oil did not suffer deterioration, suggesting that oregano oil could inhibit the growth of Bacillus subtilis.

Results also showed that oregano oil was more effective in diluted tahini than in undiluted tahini at $4{ }^{\circ} \mathrm{C}$. In undiluted tahini, $1.47 \mathrm{Log} \mathrm{CFU} / \mathrm{g}$ reduction was observed with $3 \%$ oregano oil compared to $0.67 \mathrm{log} \mathrm{CFU} / \mathrm{g}$ reduction in the control, while $3.57 \mathrm{log}$ $\mathrm{CFU} / \mathrm{g}$ reduction in diluted tahini compared to no reduction in the control after 7 days at $4{ }^{\circ} \mathrm{C}$. Diluted tahini used in this study had less fat, more water content and better fluidity than undiluted tahini. It is reported that increased fat content has a negative effect on the antimicrobial efficacy of EOs in model foods, such as peanut paste [42], soft cheese with different fat content [43] or model media containing different concentrations of sunflower oil [44]. In addition, water content is also a nonnegligible factor because water facilitates the movement of antimicrobial compounds to the target site in the bacterial cell [42].

As shown in Figure 5B and Table 4, the antimicrobial activity of $\varepsilon$-PL in diluted tahini depended on its concentration at $25^{\circ} \mathrm{C}$. $\varepsilon$-PL inhibited the growth of $S$. montevideo CICC21588 for $4 \mathrm{~h}$ with $0.05 \% \varepsilon$-PL and for $72 \mathrm{~h}$ with $0.5 \% \varepsilon$-PL. However, after 7 days at $25^{\circ} \mathrm{C}$, the populations reached the maximum numbers of approximately $9 \log \mathrm{CFU} / \mathrm{g}$. While at $4{ }^{\circ} \mathrm{C}, \mathrm{S}$. montevideo CICC21588 population remained stable for $72 \mathrm{~h}$, about $6 \log$ $\mathrm{CFU} / \mathrm{g}$ with the addition of $0.05-0.5 \%$ e-PL (Figure $5 \mathrm{~b}$ ) and after 7 days, the population was reduced to 4.59 and $3.68 \log \mathrm{CFU} / \mathrm{g}$ with $0.4 \%$ and $0.5 \% \varepsilon$-PL, respectively (Table 4 ). Furthermore, diluted tahini samples with $0.05-0.5 \% \varepsilon$-PL did not suffer deterioration, suggesting that $\varepsilon$-PL could effectively inhibit the growth of Bacillus subtilis. Previous researches have reported the antimicrobial activity of $\varepsilon$-PL in various foods. The addition of $1.5 \% \varepsilon-\mathrm{PL}$ extended lag time $(11.61 \mathrm{~h})$ of $S$. typhimurium compared to the control $(5.56 \mathrm{~h})$ in pork at $24{ }^{\circ} \mathrm{C}$ [45]. Chang et al. [20] found that $0.1-1 \% \varepsilon$-PL reduced the $S$. typhimurium population by $0.68-4.93 \log \mathrm{CFU} / \mathrm{g}$ in roast beef after 7 days at $4{ }^{\circ} \mathrm{C}$. However, some researchers found that $\varepsilon$-PL could exhibit excellent effect at particularly low concentrations. Geornaras and Sofos [46] found that $0.01 \% \varepsilon$-PL showed pronounced effect against S. typhimurium in TSAYE on day 6 at $4{ }^{\circ} \mathrm{C}$. Furthermore, Geornaras, Yoon, Belk, Smith and Sofos [47] also demonstrated that $0.04 \% \varepsilon$-PL reduced the $S$. typhimurium populations to low levels even below the detection limit in fat-free/whole fat milk, beef, bologna, ice and vegetables at $12{ }^{\circ} \mathrm{C}$ on day 6 and the antimicrobial activity was influenced by food composition.

As reported by previous studies, $\varepsilon$-PL has been widely used to control pathogens in high water foods but rarely in LMFs. In this study, $\varepsilon$-PL did not exhibit any antimicrobial activity in undiluted tahini (Figure 4 b), possibly due to the limited movement of antimicrobial compounds to the target site in the bacterial cell and the protective effect of high fat content [20].

As shown in Figure 5C and Table 4, 0.05-0.5\% CA concentration dependently slowed down the growth rate of $S$. montevideo CICC21588 in diluted tahini at $25^{\circ} \mathrm{C}$ within $24 \mathrm{~h}$ due to the decrease of $\mathrm{pH}$ value ( $\mathrm{pH}$ 5.53-4.95). The population reached to similar levels of 8.85-9.06 $\log$ CFU/g at $52 \mathrm{~h}$ in the absence or presence of CA. However, after $7 \mathrm{~d}$, samples with CA suffered deterioration and influenced the Salmonella enumeration, indicating that $0.05-0.5 \%$ CA had no antibacterial effect on Bacillus subtilis. While during the period of 7 days at $4{ }^{\circ} \mathrm{C}, 0.3 \%$ and $0.5 \% \mathrm{CA}$ had no antimicrobial activity against $S$. montevideo in diluted tahini and kept stable populations of about $6 \log \mathrm{CFU} / \mathrm{g}$ (Figure 5c, Table 4). Osaili et al. [48] also found that $0.4-0.8 \%$ CA had no significant effect on the S. typhimurium in eggplant dip samples during storage of 15 days at 4,10 and $21^{\circ} \mathrm{C}$. In tabbouleh salad, $1 \%$ $\mathrm{CA}$ exhibited no inhibition against $S$. typhimurium at $21^{\circ} \mathrm{C}$ but was effective at $4{ }^{\circ} \mathrm{C}$ or $10{ }^{\circ} \mathrm{C}$ after 7 days [49]. 
In addition, CA exhibited immediate antimicrobial effect against Salmonella in water or food surface possibly due to the lack of protective composition [50,51]. For example, $0.5 \%$ CA caused $1.26 \log$ CFU/mL reduction of Salmonella in washing water of lettuce residues within $15 \mathrm{~min}$ of contact [52].

\subsection{Synergistic Effects of Thermal Inactivation and Antimicrobials in Undiluted or Diluted Tahini}

As shown in Figure 6, oregano oil, $\varepsilon$-PL or CA concentration dependently raised the thermal $\left(56^{\circ} \mathrm{C}\right.$ for $8 \mathrm{~min}$ ) inactivation of S. montevideo CICC 21588 in diluted tahini. However, the combined treatment of $0.05-0.4 \%$ tea polyphenols and heating at $56{ }^{\circ} \mathrm{C}$ for 8 min exhibited no synergistic effect on the S. montevideo CICC 21588 inactivation $(p>0.05)$.
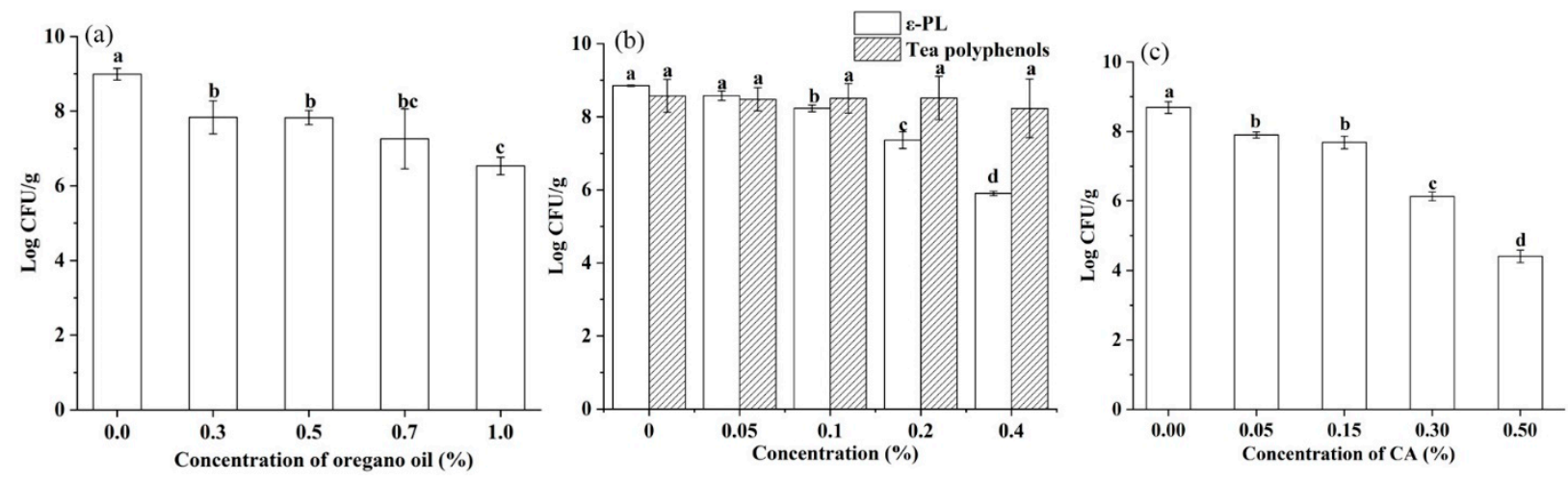

Figure 6. Synergistic antibacterial effects of heating $\left(56^{\circ} \mathrm{C}\right.$ for $\left.8 \mathrm{~min}\right)$ and antimicrobials ((a): oregano oil, (b): $\varepsilon$-PL and tea polyphenol, (c): CA) against S. montevideo CICC 21588 in diluted tahini at different concentrations. The same low case letter among different concentration treated samples indicates values are not significantly different $(p>0.05)$.

Figure 7 shows the inactivation curves of $S$. montevideo CICC21588 of heating combined with $1 \%$ oregano oil or $0.4 \% \varepsilon$-PL or $0.3 \%$ CA. Table 5 further shows the $\delta$ - and $p$-values of the Weibull model for thermal inactivation in combination with antimicrobials. The $\delta$-values at $56{ }^{\circ} \mathrm{C}$ combined with $1 \%$ oregano oil, $0.4 \% \varepsilon$-PL or $0.3 \%$ CA were $3.98 \mathrm{~min}$, $4.20 \mathrm{~min}$ and $4.92 \mathrm{~min}$, respectively, while the $\delta$-value was $16.46 \mathrm{~min}$ by heating alone at $56{ }^{\circ} \mathrm{C}$. Furthermore, the $\delta$-values at $58^{\circ} \mathrm{C}$ combined with these antimicrobials were also significantly smaller than that of heating alone at $58^{\circ} \mathrm{C}(p<0.05)$, indicating that oregano oil, $\varepsilon$-PL and CA all significantly reduced the thermal resistance of S. montevideo CICC21588 in diluted tahini.

Table 5. $\delta$ - and $p$-values of the Weibull model for thermal inactivation combined with antimicrobials against $S$. montevideo CICC21588 inoculated into diluted tahini.

\begin{tabular}{|c|c|c|c|c|c|}
\hline & \multirow{2}{*}{ Temperature $\left({ }^{\circ} \mathrm{C}\right)$} & \multicolumn{4}{|c|}{ Weibull Model } \\
\hline & & $\delta$ & $p$ & $R^{2}$ & RMSE \\
\hline \multirow{2}{*}{ Diluted tahini } & 56 & $16.52 \pm 1.42^{\mathrm{a}}$ & $3.91 \pm 1.21$ & 0.973 & 0.279 \\
\hline & 58 & $4.38 \pm 0.52^{b}$ & $2.70 \pm 0.48$ & 0.993 & 0.195 \\
\hline \multirow{2}{*}{ Diluted tahini $+1 \%$ oregano oil } & 56 & $3.98 \pm 0.64^{b}$ & $1.30 \pm 0.21$ & 0.983 & 0.201 \\
\hline & 58 & $1.94 \pm 0.06^{\mathrm{c}}$ & $4.57 \pm 0.39$ & 0.994 & 0.123 \\
\hline \multirow{2}{*}{ Diluted tahini $+0.4 \% \varepsilon-\mathrm{PL}$} & 56 & $4.20 \pm 0.13^{b}$ & $1.87 \pm 0.02$ & 0.976 & 0.333 \\
\hline & 58 & $1.25 \pm 0.03^{c}$ & $2.04 \pm 0.19$ & 0.991 & 0.194 \\
\hline \multirow{2}{*}{ Diluted tahini+0.3\% CA } & 56 & $4.92 \pm 1.13^{b}$ & $2.24 \pm 0.73$ & 0.971 & 0.313 \\
\hline & 58 & $1.35 \pm 0.11^{\mathrm{c}}$ & $2.66 \pm 0.30$ & 0.980 & 0.299 \\
\hline
\end{tabular}

The same lower case letter with a column among different samples and temperatures indicates mean values are not significantly different $(p>0.05)$. 

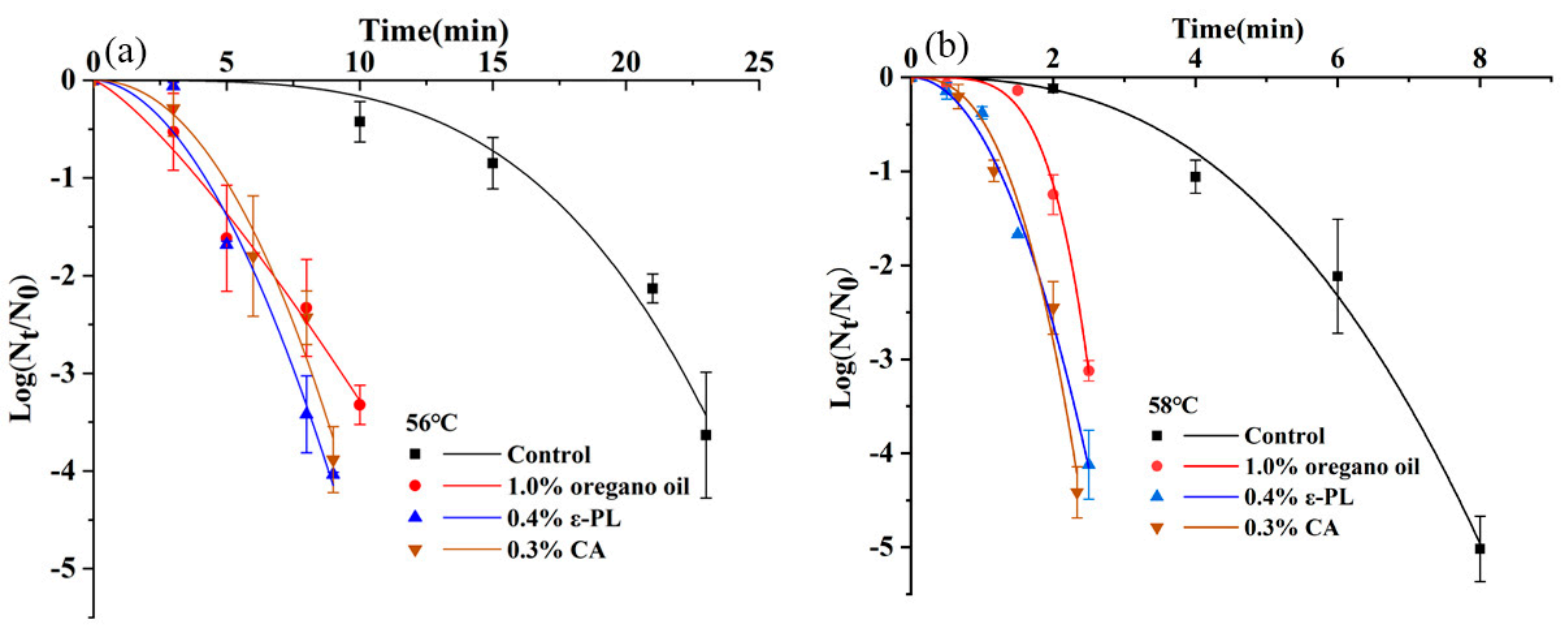

Figure 7. Inactivation curves of $S$. montevideo $\mathrm{CICC} 21588$ in diluted tahini using heating $\left((\mathbf{a}): 56{ }^{\circ} \mathrm{C}\right.$ or $\left.(\mathbf{b}): 58{ }^{\circ} \mathrm{C}\right)$ combined with oregano oil, CA and $\varepsilon-$ PL.

From Table 6 , no synergistic effect was observed at $75{ }^{\circ} \mathrm{C}$ with $2 \%$ oregano oil. The addition of water-soluble antimicrobials raised the $\mathrm{a}_{\mathrm{w}}$ of tahini samples, which influenced the thermal resistance of Salmonella [31]. The $\mathrm{a}_{\mathrm{w}}$ increased from 0.256 of original sample to 0.283 or 0.335 of samples with $0.3 \%$ CA or $0.4 \% \varepsilon-P L$. Therefore, the $a_{w}$ of control group samples was adjusted to the same with antimicrobials treated samples. Although the $\delta$-values at $75{ }^{\circ} \mathrm{C}$ with $0.3 \% \mathrm{CA}$ or $0.4 \% \varepsilon$-PL significantly decreased as compared to the respective control $(p<0.05)$, significant differences between the population reductions were only observed at $75{ }^{\circ} \mathrm{C}$ for $20 \mathrm{~min}(p<0.05)$ and no significant difference at $75{ }^{\circ} \mathrm{C}$ for 40-100 $\min (p>0.05)$, indicating that the addition of CA and $\varepsilon$-PL in undiluted tahini slightly reduced the thermal resistance of $S$. montevideo CICC21588 but the synergistic effects were far lower than those in diluted tahini samples.

The different synergistic effects obtained between undiluted and diluted tahini may be due to the lower sublethal injured cells caused by thermal treatments in undiluted tahini compared to that in diluted tahini (Figure 3). Antimicrobials could inactivate the sublethal injured cells caused by heating more easily than intact cells through enhanced access to target cell structures [28]. In addition, the synergistic effect may also be the result of the cumulative stresses occurring over a short period, causing multiple damages of bacteria cells so that losing the ability of the bacteria to recover [23]. For example, EOs have been reported to inactivate pathogens through alternating the fatty acid profile of cell membrane, disrupting the cytoplasmic membrane, and reducing the proton-motive force (PMF) [53]. $\varepsilon$-PL could also alter the integrity and permeability of cell membranes of Escherichia coli O157:H7 [54]. For organic acids, their undissociated form can easily pass through the bacterial membrane and dissociate, resulting in the reduced $\mathrm{pH}$ value of the internal cell, finally leading to the cell death [55]. Furthermore, synergistic effects of heating and antimicrobials were widely observed in food surface, juice, milk, various meat products or other foods with high water content but rarely in oily, low $\mathrm{a}_{\mathrm{w}}$ paste-like foods, such as tahini, peanut paste or nut paste, due to the limited effect in these foods. Espina et al. [35] reported that the combination treatment of orange essential oil or (+)limonene and mild heat had a synergistic bactericidal effect on E. coli O157:H7 in orange juice. Sun-Ah et al. [56] found that superheated steam combined with lactic acid could be used to inactivate food pathogens on cantaloupe surface. Oregano essential oil and CA also raised thermal sensitivity of Listeria monocytogenes in sous-vide salmon [57]. 
Table 6. Synergistic effects of thermal inactivation in combination with antimicrobials against S. montevideo CICC21588 inoculated into undiluted tahini.

\begin{tabular}{|c|c|c|c|c|c|c|c|c|c|}
\hline \multirow{3}{*}{ Samples } & \multirow{3}{*}{$a_{w}$} & \multicolumn{4}{|c|}{$75^{\circ} \mathrm{C}+$ Holding Time $(\mathrm{min})$} & \multirow{2}{*}{\multicolumn{4}{|c|}{ Weibull Model }} \\
\hline & & \multicolumn{4}{|c|}{ Population Reduction (Log CFU/g) } & & & & \\
\hline & & 20 & 40 & 70 & 100 & $\delta$ & $p$ & $R^{2}$ & RMSE \\
\hline Undiluted tahini $+2 \%$ oregano oil & $0.256 \pm 0.002$ & $1.13 \pm 0.01^{\mathrm{a}}$ & $1.79 \pm 0.02^{\mathrm{a}}$ & $2.36 \pm 0.18^{a}$ & $2.52 \pm 0.21^{\mathrm{a}}$ & $12.48 \pm 1.46^{\mathrm{a}}$ & $0.53 \pm 0.03$ & 0.986 & 0.028 \\
\hline Undiluted tahini & \multirow{2}{*}{$0.283 \pm 0.012$} & $1.58 \pm 0.02^{b}$ & $1.68 \pm 0.10^{\mathrm{a}}$ & $2.84 \pm 0.12^{\mathrm{ab}}$ & $3.16 \pm 0.10^{b c}$ & $10.29 \pm 0.35^{\mathrm{a}}$ & $0.51 \pm 0.01$ & 0.965 & 0.266 \\
\hline Undiluted tahini $+0.3 \% \mathrm{CA}$ & & $1.82 \pm 0.16^{\mathrm{c}}$ & $2.22 \pm 0.02^{\mathrm{ab}}$ & $2.86 \pm 0.09 \mathrm{abc}$ & $3.32 \pm 0.06^{\mathrm{bc}}$ & $4.72 \pm 1.26^{\mathrm{b}}$ & $0.39 \pm 0.03$ & 0.998 & 0.059 \\
\hline Undiluted tahini $+0.4 \%$ $\varepsilon-\mathrm{PL}$ & $0.335 \pm 0.004$ & $2.33 \pm 0.14^{\mathrm{d}}$ & $2.84 \pm 0.19^{c}$ & $3.23 \pm 0.28^{b c}$ & $3.48 \pm 0.07^{\mathrm{c}}$ & $0.61 \pm 0.09^{c}$ & $0.23 \pm 0.03$ & 0.999 & 0.016 \\
\hline
\end{tabular}

The same lower case letter with a column among different samples indicates mean values are not significantly different $(p>0.05)$. 


\section{Conclusions}

The present study compared effects of hydrophobic antimicrobials, oregano oil and hydrophilic antimicrobials, $\varepsilon$-PL and CA on Salmonella inactivation in undiluted and diluted tahini during thermal treatment and storage. Oregano oil and CA had antimicrobial effects against $S$. montevideo CICC21588 in undiluted tahini during the storage period of 7 days at $4{ }^{\circ} \mathrm{C}$ or $25^{\circ} \mathrm{C}$. However, only high concentration of oregano oil $(3 \%)$ exhibited a satisfactory effect but might cause undesirable flavor. In diluted tahini, oregano oil, $\varepsilon-\mathrm{PL}$ and CA all could inhibit the growth of S. montevideo CICC21588 at $25^{\circ} \mathrm{C}$ to varying degrees and $\varepsilon$-PL had the best inhibitory effect. These antimicrobials all enhanced Salmonella inactivation effects in diluted tahini during thermal treatment. Further research may focus on developing combination of natural antimicrobials to further enhance synergistic effects and reduce the unfriendly flavor in treated products. In addition, the safety and quality including sensory evaluation of tahini samples with these antimicrobials should be considered in further studies. This study may provide some useful information for thermal inactivation of Salmonella in tahini or tahini-based products and selecting effective appropriate antimicrobials for practical pasteurization.

Author Contributions: Y.X. conducted experiments and developed predicted model for analyzing data, and wrote the first version of manuscript; X.G. provided the microbial strains and evaluated the microbial populations; B.L. helped to analyzing data; R.L. helped to develop the models; S.W. is the principal investigator of the project, guided the experimental design and revised manuscript. All authors have read and agreed to the published version of the manuscript.

Funding: This research was supported by research grants from General Program of National Natural Science Foundation of China (31772031), and National Key Research and Development Program of China (2018YFD0700100).

Data Availability Statement: The datasets generated for this study are available on request to the corresponding author.

Acknowledgments: The authors thank Juanjuan $\mathrm{Xu}$ and Gaoji Yang for their help in conducting experiments.

Conflicts of Interest: The authors declare no conflict of interest.

\section{References}

1. El-Adawy, T.A.; Mansour, E.H. Nutritional and physicochemical evaluations of tahina (sesame butter) prepared from heat-treated sesame seeds. J. Sci. Food Agric. 2000, 80, 2005-2011. [CrossRef]

2. Al-Nabulsi, A.A.; Osaili, T.M.; Olaimat, A.N.; Almasri, W.E.; Ayyash, M.; Al-Holy, M.A.; Jaradat, Z.W.; Obaid, R.S.; Holley, R.A. Inactivation of Salmonella spp. in tahini using plant essential oil extracts. Food Microbiol. 2020, 86, 103338. [CrossRef]

3. Olaimat, A.N.; Al-Holy, M.A.; Abu Ghoush, M.; Al-Nabulsi, A.A.; Holley, R.A. Control of Salmonella enterica and Listeria monocytogenes in hummus using allyl isothiocyanate. Int. J. Food Microbiol. 2018, 278, 73-80. [CrossRef]

4. Osaili, T.M.; Al-Nabulsi, A.A.; Aljaafreh, T.F.; Olaimat, A.N. Use of gamma radiation to inactivate stressed Salmonella spp.; Escherichia coli O157:H7 and Listeria monocytogenes in tahini halva. LWT Food Sci. Technol. 2018, 98, 438-443. [CrossRef]

5. Salazar, J.K.; Natarajan, V.; Stewart, D.; Fay, M.; Gonsalves, L.J.; Mhetras, T.; Sule, C.; Tortorello, M.L. Listeria monocytogenes growth kinetics in refrigerated ready-to-eat dips and dip components. PLoS ONE 2020, 15, e0235472. [CrossRef] [PubMed]

6. Ren, X.; Lou, G.; Shen, Q. Effect of high-pressure thermal sterilization on quality attributes of compound sesame paste. J. Chin. Inst. Food Sci. Tech. 2016, 16, 140-148. (In Chinese) [CrossRef]

7. Brockmann, S.O.; Piechotowski, I.; Kimmig, P. Salmonella in sesame seed products. J. Food Prot. 2004, 67, 178-180. [CrossRef]

8. Unicomb, L.E.; Simmons, G.; Merritt, T.; Gregory, J.; Nicol, C.; Jelfs, P.; Kirk, M.; Tan, A.; Thomson, R.; Adamopoulos, J.; et al. Sesame seed products contaminated with Salmonella: Three outbreaks associated with tahini. Epidemiol. Infect. 2005, 133, 1065-1072. [CrossRef] [PubMed]

9. Blackwell, R.; Blaylock, M.; Merid, S.; DaviesCole, J.; Gibson, A.; Herdman, D.; Sudler, R.; Lee, H.; Corvese, K.; Levine, S. Multistate outbreak of Salmonella serotype Bovismorbificans infections associated with hummus and tahini-United States, 2011. Morb. Mortal. Wkly. Rep. 2012, 61, 944-947.

10. Paine, S.; Thornley, C.; Wilson, M.; Dufour, M.; Sexton, K.; Miller, J.; King, G.; Bell, S.; Bandaranayake, D.; Mackereth, G. An outbreak of multiple serotypes of Salmonella in New Zealand linked to consumption of contaminated tahini imported from Turkey. Foodborne Pathog. Dis. 2014, 11, 887-892. [CrossRef] 
11. Centers for Disease Control and Prevention (CDC). Multistate outbreak of Salmonella montevideo and Salmonella mbandaka Infections Linked to Tahini Sesame Paste (Final Update). 2013. Available online: https://www.cdc.gov/salmonella/montevideo-tahini-05 -13/index.html (accessed on 15 February 2021).

12. Meinen, A.; Simon, S.; Banerji, S.; Szabo, I.; Malorny, B.; Borowiak, M.; Hadziabdic, S.; Becker, N.; Luber, P.; Lohr, D.; et al. Salmonellosis outbreak with novel Salmonella enterica subspecies enterica serotype (11: z41: E, n, z15) attributable to sesame products in five European countries, 2016 to 2017. Eurosurveillance 2019, 24, 6-14. [CrossRef]

13. Centers for Disease Control and Prevention (CDC). Outbreak of Salmonella Infections Linked to Tahini from Achdut Ltd. 2018. Available online: https:/ /www.cdc.gov/salmonella/concord-11-18/index.html (accessed on 15 February 2021).

14. Centers for Disease Control and Prevention (CDC). Outbreak of Salmonella Infections Linked to Karawan Brand Tahini. 2019. Available online: https:/ /www.cdc.gov/salmonella/concord-05-19/index.html (accessed on 15 February 2021).

15. Olaimat, A.N.; Osaili, T.M.; Al-Holy, M.A.; Al-Nabulsi, A.A.; Obaid, R.S.; Alaboudi, A.R.; Ayyash, M.; Holley, R. Microbial safety of oily, low water activity food products: A review. Food Microbiol. 2020, 92, 103571. [CrossRef]

16. Torlak, E.; Sert, D.; Serin, P. Fate of Salmonella during sesame seeds roasting and storage of tahini. Int. J. Food Microbiol. 2013, 163, 214-217. [CrossRef]

17. Zhang, Y.J.N.; Keller, S.E.; Grasso-Kelley, E.M. Fate of Salmonella throughout production and refrigerated storage of tahini. J. Food Prot. 2017, 80, 940-946. [CrossRef] [PubMed]

18. Aviles, B.; Klotz, C.; Smith, T.; Williams, R.; Ponder, M. Survival of Salmonella enterica serotype Tennessee during simulated gastric passage is improved by low water activity and high fat content. J. Food Prot. 2013, 76, 333-337. [CrossRef] [PubMed]

19. Bhargava, K.; Conti, D.S.; da Rocha, S.R.P.; Zhang, Y.F. Application of an oregano oil nanoemulsion to the control of foodborne bacteria on fresh lettuce. Food Microbiol. 2015, 47, 69-73. [CrossRef]

20. Chang, S.S.; Lu, W.Y.W.; Park, S.H.; Kang, D.H. Control of foodborne pathogens on ready-to-eat roast beef slurry by epsilonpolylysine. Int. J. Food Microbiol. 2010, 141, 236-241. [CrossRef]

21. Mortazavi, N.; Aliakbarlu, J. Antibacterial effects of ultrasound, cinnamon essential oil, and their combination against Listeria monocytogenes and Salmonella Typhimurium in milk. J. Food Sci. 2019, 84, 3700-3706. [CrossRef] [PubMed]

22. Ha, J.W.; Kang, D.H. Combining lactic acid spray with NIR radiant heating to inactivate Salmonella enterica Serovar Enteritidis on almond and pine nut kernels. Appl. Environ. Microbiol. 2015, 81, 4517-4524. [CrossRef]

23. Zhang, H.C.; Tikekar, R.V.; Ding, Q.; Gilbert, A.R.; Wimsatt, S.T. Inactivation of foodborne pathogens by the synergistic combinations of food processing technologies and food-grade compounds. Compr. Rev. Food. Sci. Food Saf. 2020, 19, $2110-2138$. [CrossRef]

24. Kou, X.X.; Li, R.; Hou, L.X.; Huang, Z.; Ling, B.; Wang, S.J. Performance of a heating block system designed for studying the heat resistance of bacteria in foods. Sci. Rep. 2016, 6, 1-12. [CrossRef]

25. Bian, X.; Evivie, S.E.; Muhammad, Z.; Luo, G.W.; Liang, H.Z.; Wang, N.N.; Huo, G.C. In vitro assessment of the antimicrobial potentials of Lactobacillus helveticus strains isolated from traditional cheese in Sinkiang China against food-borne pathogens. Food. Funct. 2016, 7, 789-797. [CrossRef]

26. Wang, X.; Devlieghere, F.; Geeraerd, A.; Uyttendaele, M. Thermal inactivation and sublethal injury kinetics of Salmonella enterica and Listeria monocytogenes in broth versus agar surface. Int. J. Food Microbiol. 2017, 243, 70-77. [CrossRef] [PubMed]

27. Sanz-Puig, M.; Santos-Carvalho, L.; Cunha, L.M.; Pina-Perez, M.C.; Martinez, A.; Rodrigo, D. Effect of pulsed electric fields (PEF) combined with natural antimicrobial by-products against S. typhimurium. Innov. Food Sci. Emerg. Technol. 2016, 37, 322-328. [CrossRef]

28. Espina, L.; Somolinos, M.; Ouazzou, A.A.; Condon, S.; Garcia-Gonzalo, D.; Pagan, R. Inactivation of Escherichia coli O157:H7 in fruit juices by combined treatments of citrus fruit essential oils and heat. Int. J. Food Microbiol. 2012, 159, 9-16. [CrossRef] [PubMed]

29. He, Y.S.; Li, Y.; Salazar, J.K.; Yang, J.Y.; Tortorello, M.L.; Zhang, W. Increased water activity reduces the thermal resistance of Salmonella enterica in peanut butter. Appl. Environ. Microbiol. 2013, 79, 4763-4767. [CrossRef] [PubMed]

30. Krapf, T.; Gantenbein-Demarchi, C. Thermal inactivation of Salmonella spp. during conching. LWT-Food Sci. Technol. 2010, 43, 720-723. [CrossRef]

31. Gautam, B.; Govindan, B.N.; Gänzle, M.; Roopesh, M.S. Influence of water activity on the heat resistance of Salmonella enterica in selected low-moisture foods. Int. J. Food Microbiol. 2020, 334, 108813. [CrossRef]

32. Li, C.C.; Huang, L.H.; Chen, J.Q. Comparative study of thermal inactivation kinetics of Salmonella spp. in peanut butter and peanut butter spread. Food Control 2014, 45, 143-149. [CrossRef]

33. Ban, C.; Lee, D.H.; Jo, Y.; Bae, H.; Seong, H.; Kim, S.O.; Lim, S.; Choi, Y.J. Use of superheated steam to inactivate Salmonella enterica serovars Typhimurium and Enteritidis contamination on black peppercorns, pecans, and almonds. J. Food Eng. 2018, 222, $284-291$. [CrossRef]

34. Gurtler, J.B.; Juneja, V.K.; Jones, D.R.; Purohit, A. Thermal inactivation kinetics of three heat-resistant Salmonella strains in whole liquid egg. J. Food Prot. 2019, 82, 1465-1471. [CrossRef]

35. Espina, L.; Condon, S.; Pagan, R.; Garcia-Gonzalo, D. Synergistic effect of orange essential oil or (+)-limonene with heat treatments to inactivate Escherichia coli O157:H7 in orange juice at lower intensities while maintaining hedonic acceptability. Food Bioprocess Technol. 2014, 7, 471-481. [CrossRef] 
36. Maria Cava-Roda, R.; Taboada, A.; Palop, A.; Lopez-Gomez, A.; Marin-Iniesta, F. Heat resistance of Listeria monocytogenes in semi-skim milk supplemented with vanillin. Int. J. Food Microbiol. 2012, 157, 314-318. [CrossRef]

37. Lee, S.Y.; Oh, S.W.; Ghung, H.J.; Reyes-De-Corchuera, J.I.; Powers, J.R.; Kang, D.H. Reduction of Salmonella enterica Serovar Enteritidis on the surface of raw shelled almonds by exposure to steam. J. Food Prot. 2006, 69, 591-595. [CrossRef] [PubMed]

38. Mani-Lopez, E.; Garcia, H.S.; Lopez-Malo, A. Organic acids as antimicrobials to control Salmonella in meat and poultry products. Food Res. Int. 2012, 45, 713-721. [CrossRef]

39. Farakos, S.M.S.; Pouillot, R.; Keller, S.E. Salmonella survival kinetics on pecans, hazelnuts, and pine nuts at various water activities and temperatures. J. Food Prot. 2017, 80, 879-885. [CrossRef] [PubMed]

40. Park, E.J.; Oh, S.W.; Kang, D.H. Fate of Salmonella Tennessee in peanut butter at 4 and $22{ }^{\circ}$ C. J. Food Sci. 2008, 73 , M82-M86. [CrossRef] [PubMed]

41. Al-Nabulsi, A.A.; Olaimat, A.N.; Osaili, T.M.; Shaker, R.R.; Elabedeen, N.Z.; Jaradat, Z.W.; Abushelaibi, A.; Holley, R.A. Use of acetic and citric acids to control Salmonella Typhimurium in tahini (sesame paste). Food Microbiol. 2014, 42, 102-108. [CrossRef] [PubMed]

42. Chen, W.; Golden, D.A.; Critzer, F.J.; Davidson, P.M. Antimicrobial activity of cinnamaldehyde, carvacrol, and lauric arginate against Salmonella Tennessee in a glycerol-sucrose model and peanut paste at different fat concentrations. J. Food Prot. 2015, 78, 1488-1495. [CrossRef]

43. Smith-Palmer, A.; Stewart, J.; Fyfe, L. The potential application of plant essential oils as natural food preservatives in soft cheese. Food Microbiol. 2001, 18, 463-470. [CrossRef]

44. Gutierrez, J.; Barry-Ryan, C.; Bourke, R. The antimicrobial efficacy of plant essential oil combinations and interactions with food ingredients. Int. J. Food Microbiol. 2008, 124, 91-97. [CrossRef]

45. Min, K.-J.; Kwon, K.-Y.; Yoon, K.-S. Effect of various antimicrobials on the growth kinetics of foodborne pathogens in ready-to-eat, pyeonyuk (cooked and pressed pork). Food Sci. Biotechnol. 2010, 19, 99-106. [CrossRef]

46. Geornaras, I.; Sofos, J.N. Activity of epsilon-polylysine against Escherichia coli O157: H7, Salmonella Typhimurium, and Listeria monocytogenes. J. Food Sci. 2005, 70, M404-M408. [CrossRef]

47. Geornaras, I.; Yoon, Y.; Belk, K.E.; Smith, G.C.; Sofos, J.N. Antimcrobial activity of epsilon-polylyrsine against Escherichia coli O157:H7, Salmonella Typhimurium, and Listeria manocytogenes in various food extracts. J. Food Sci. 2007, 72, M330-M334. [CrossRef]

48. Osaili, T.M.; Al-Nabulsi, A.A.; Jaradat, Z.; Shaker, R.R.; Alomari, D.Z.; Al-Dabbas, M.M.; Alaboudi, A.R.; Al-Natour, M.Q.; Holley, R.A. Survival and growth of Salmonella Typhimurium, Escherichia coli O157: H7 and Staphylococcus aureus in eggplant dip during storage. Int. J. Food Microbiol. 2015, 198, 37-42. [CrossRef]

49. Al-Rousan, W.M.; Olaimat, A.N.; Osaili, T.M.; Al-Nabulsi, A.A.; Ajo, R.Y.; Holley, R.A. Use of acetic and citric acids to inhibit Escherichia coli O157:H7, Salmonella Typhimurium and Staphylococcus aureus in tabbouleh salad. Food Microbiol. 2018, 73, 61-66. [CrossRef]

50. Kang, J.H.; Song, K.B. Inactivation of pre-existing bacteria and foodborne pathogens on perilla leaves using a combined treatment with an organic acid and a surfactant. Hortic. Environ. Biotechnol. 2015, 56, 195-199. [CrossRef]

51. Park, S.H.; Choi, M.R.; Park, J.W.; Park, K.H.; Chung, M.S.; Ryu, S.; Kang, D.H. Use of organic acids to inactivate Escherichia coli O157:H7, Salmonella Typhimurium, and Listeria monocytogenes on organic fresh apples and lettuce. J. Food Sci. 2011, 76, M293-M298. [CrossRef]

52. Borges, T.J.; Moretti, L.K.; Silva, M.M.N.; Tondo, E.C.; Pereira, K.S. Salmonella sensitivity to sodium hypochlorite and citric acid in washing water of lettuce residues. J. Food Saf. 2020, 40, e12748. [CrossRef]

53. Rao, J.J.; Chen, B.C.; McClement, D.J. Improving the efficacy of essential oils as antimicrobials in foods: Mechanisms of action. Ann. Rev. Food Sci. Technol. 2019, 10, 365-387. [CrossRef] [PubMed]

54. Zhang, X.W.; Shi, C.; Liu, Z.J.; Pan, F.G.; Meng, R.Z.; Bu, X.J.; Xing, H.Q.; Deng, Y.H.; Guo, N.; Yu, L. Antibacterial activity and mode of action of epsilon-polylysine against Escherichia coli O157: H7. J. Med. Microbiol. 2018, 67, 838-845. [CrossRef] [PubMed]

55. Mohan, A.; Purohit, A.S. Anti-Salmonella activity of pyruvic and succinic acid in combination with oregano essential oil. Food Control 2020, 110, 106960. [CrossRef]

56. Kwon, S.A.; Song, W.J.; Kang, D.H. Combination effect of saturated or superheated steam and lactic acid on the inactivation of Escherichia coli O157:H7, Salmonella typhimurium and Listeria monocytogenes on cantaloupe surfaces. Food Microbiol. 2019, 82, 342-348. [CrossRef] [PubMed]

57. Dogruyol, H.; Mol, S.; Cosansu, S. Increased thermal sensitivity of Listeria monocytogenes in sous-vide salmon by oregano essential oil and citric acid. Food Microbiol. 2020, 90, 103496. [CrossRef] [PubMed] 